\title{
Brain-Derived Neurotrophic Factor Participates in Determination of Neuronal Laminar Fate in the Developing Mouse Cerebral Cortex
}

\author{
Hidefumi Fukumitsu, ${ }^{1}$ Masanari Ohtsuka, ${ }^{1}$ Rina Murai, ${ }^{1}$ Hiroyuki Nakamura, ${ }^{2}$ Kazuo Itoh, ${ }^{2}$ Shoei Furukawa ${ }^{1}$ \\ ${ }^{1}$ Laboratory of Molecular Biology, Gifu Pharmaceutical University, Gifu 502-8585, Japan, and ${ }^{2}$ Department of Morphological Neuroscience, Gifu University \\ Graduate School of Medical Science, Gifu 501-1194, Japan
}

\begin{abstract}
Lamina formation in the developing cerebral cortex requires precisely regulated generation and migration of the cortical progenitor cells. To test the possible involvement of brain-derived neurotrophic factor (BDNF) in the formation of the cortical lamina, we investigated the effects of BDNF protein and anti-BDNF antibody separately administered into the telencephalic ventricular space of 13.5-d-old mouse embryos. BDNF altered the position, gene-expression properties, and projections of neurons otherwise destined for layer IV to those of neurons for the deeper layers, V and VI, of the cerebral cortex, whereas anti-BDNF antibody changed some of those of neurons of upper layers II/III. Additional analysis revealed that BDNF altered the laminar fate of neurons only if their parent progenitor cells were exposed to it at approximately S-phase and that it hastened the timing of the withdrawal of their daughter neurons from the ventricular proliferating pool by accelerating the completion of S-phase, downregulation of the Pax6 (paired box gene 6) expression, an essential transcription factor for generation of the upper layer neurons, and interkinetic nuclear migration of cortical progenitors in the ventricular zone. These observations suggest that BDNF participates in the processes forming the neuronal laminas in the developing cerebral cortex. BDNF can therefore be counted as one of the key extrinsic factors that regulate the laminar fate of cortical neurons.
\end{abstract}

Key words: brain-derived neurotrophic factor (BDNF); neurotrophin; laminar fate; neocortex; interkinetic migration; precocious neurogenesis

\section{Introduction}

The cerebral cortex is organized into six cell layers, each of which contains neurons with similar morphology, functions, geneexpression profiles, and projection patterns (Gilbert and Kelly, 1975; Gilbert and Wiesell, 1985). These layer-specific neuronal phenotypes are sequentially generated in the ventricular zone (VZ) of the dorsal telencephalon, and postmitotic neurons migrate to their destinations within the cortical plate (CP), in which later-born neurons migrate over earlier-born deeper-layer neurons and occupy more superficial layers (Angenvine and Sidman, 1961; Rakic, 1974). Recent genetic studies have identified various molecules involved in these processes (Rice and Curran, 1999; Soriano and del Rio, 2005). For instance, reelin, a protein secreted from Cajal-Retzuis (CR) neurons, regulates the migration and positioning of postmitotic neurons. Reeler mutant mice lack the machinery for inside-out cell migration because of mutated reelin gene, and their neuronal layers are arranged in the opposite order. However, neuronal properties are those appropriate to the

Received 0ct. 7, 2005; revised Nov. 13, 2006; accepted Nov. 17, 2006.

This work was supported in part by a Health Science Research Grant on Brain Science from the Ministry of Health and Welfare of Japan. We thank Dr. Susan K. McConnell for ROR- $\beta$ cDNA, Dr. Ahmed Mansouri for Pax6 and Cux1 cDNAs, and Yumiko Yamada-Ito for excellent technical assistance.

Correspondence should be addressed to Shoei Furukawa, Laboratory of Molecular Biology, Gifu Pharmaceutical University, Mitahora-higashi 5-6-1, Gifu 502-8585, Japan. E-mail: furukawa@gifu-pu.ac.jp.

D01:10.1523/JNEUROSCI.4251-06.2006

Copyright $\odot 2006$ Society for Neuroscience $\quad$ 0270-6474/06/2613218-13\$15.00/0 layers regardless of the altered positioning of the neurons (Polleux et al., 1998; Tarabykin et al., 2001), demonstrating as-yetunclarified molecular mechanisms that underlie the generation of layer-specific neuronal subtypes.

Both intrinsic mechanisms and environmental signals are likely to be involved in cell diversification during development of the cerebral cortex. The expression of intrinsic cues such as neurogenetic transcription factors (Hevner et al., 2001; Schuurmans et al., 2004) and spatiotemporally regulated cell-cycle regulators (Caviness et al., 2003) have been suggested to specify the deeplayer cortical neurons. Neural progenitors in earlier stages can generate upper-layer neurons when such progenitors in S-phase are transplanted into older host brains; however, progenitors that have already passed through S-phase generate neurons that are committed to the original deep-layer fate (McConnell and Kaznowski, 1991; Desai and McConnell, 2000). Thus, environmental factors are critical determinants of the laminar fate of daughter neurons, whose parent progenitors undergo cyclical changes in their ability to respond to such cues. However, the environmental cues that convey to progenitors the extracellular signals to regulate the intrinsic cues determining laminar fate have not yet been elucidated.

Brain-derived neurotrophic factor (BDNF) is a probable candidate for an environmental cue, because important roles have been postulated (Huang and Reichardt, 2001; Lu, 2003). In particular, the following previous observations prompted us to in- 
vestigate BDNF as an endogenous extracellular factor: (1) BDNF and its receptor are expressed in migrating progenitors (Maisonpierre et al., 1990; Behar et al., 1997; Fukumitsu et al., 1998); (2) intraventricular administration of BDNF alters the migratory destination of neurons (Ohmiya et al., 2002); (3) BDNF facilitates the survival and neurogenesis of cultured cortical progenitors (Barnabe-Heider and Miller, 2003); and (4) BDNF stimulates neuronal differentiation through the expression of neurogenetic transcription factors Mash1 (mammalian achaete-schute homolog 1) and Math1 (mouse atonal homolog 1) (Ito et al., 2003).

In this study, we investigated the influence of BDNF and a function-blocking antibody against BDNF on the middle stages of corticogenesis by using an in utero microinjection technique. The results obtained suggest that BDNF is involved in the processes deciding the neuronal phenotype.

\section{Materials and Methods \\ Plasmids}

cDNA corresponding to the coding region of humanized Rotylenchulus reniformis hrGFP gene (purchased as pIRES-hrGFPla from Stratagene, La Jolla, CA) was subcloned into the pCALNLw vector (donated by Dr J. Miyazaki, Osaka University, Osaka, Japan) (Kanegae et al., 1995) for expression under the control of the CAG promoter after deletion of the neomycin-resistance gene and stop codon sequences (pCAG-hrGFP).

\section{Animals}

Pregnant ddY mice were purchased from Japan SLC (Shizuoka, Japan). The mice were handled in accordance with the Guidelines of Experimental Animal Care issued by the Office of the Prime Minister of Japan. Surgery and manipulation of animals were performed as described previously (Fukumitsu et al., 1998; Ohmiya et al., 2002). Briefly, pregnant mice carrying embryonic day 13.5 (E13.5) embryos were deeply anesthetized with sodium pentobarbital (30 $\mu \mathrm{g} / \mathrm{g}$, i.p.), and the uterine horns were then exposed. After GFP expression vectors had been delivered via electroporation and/or intrauterine injection, as described below, the uteri were placed back into the abdominal cavity to allow the embryos to continue normal development. Most of the pregnant mice delivered their pups normally.

\section{Intrauterine injection and electroporation of the GFP expression vector}

Approximately 1-2 $\mu$ l of pCAG-hrGFP plasmid solution containing fast green $(2 \mu \mathrm{g} / \mu \mathrm{l}$; Sigma, St. Louis) was injected into the lateral ventricle of each embryo in the uterus via a pulled glass microcapillary (GD-1; Narishige, Tokyo, Japan). The embryo was placed between tweezer-type disc electrodes $5 \mathrm{~mm}$ in diameter at the tip (CUY650-5; Nepa Gene, Chiba, Japan) and treated with electric pulses (32 V; $50 \mathrm{~ms}) 10$ times with an electroporator (CUY21E; Nepa Gene) at $150 \mathrm{~ms}$ intervals, with a change in the angle of electroporation after the first five pulses. In the case of administration of BDNF protein $(600 \mathrm{ng} / \mathrm{embryo}$; a generous gift from Dainippon-Sumitomo Pharmaceutical, Osaka, Japan), it was injected into the ventricular space immediately after the electroporation.

\section{5'-Bromo-2'-deoxyuridine injection schedules}

For a single $5^{\prime}$-bromo- $2^{\prime}$-deoxyuridine (BrdU) injection, pregnant mice were injected intraperitoneally with $50 \mu \mathrm{g} / \mathrm{g}$ body weight of BrdU (Sigma) in sterile PBS. The schedules of BrdU injections for particular experiments are described below.

Effect of BDNF on the laminar fate of progenitor cells. For labeling neural progenitors cycling in S-phase in E13.5 embryos, pregnant mice bearing E13.5 embryos were given a single intraperitoneal injection of $\mathrm{BrdU}$ (at 5:00 P.M. on E13) $3 \mathrm{~h}$ after the ventricular injection of BDNF (at 2:00 P.M. on E13; $600 \mathrm{ng} / \mathrm{embryo})$, anti-BDNF chicken IgY antibody (2.0 $\mu \mathrm{g} /$ embryo; R \& D Systems, Minneapolis, MN), normal chicken IgY (2.0 $\mu \mathrm{g} /$ embryo), or vehicle. Normal chicken IgY was used as an Ig control. On postnatal $6 \mathrm{~d}(\mathrm{P} 6)$ or postnatal week 3 (P3W), the mice were killed by an overdose of diethyl ether, and their brains were collected.

Effects of BDNF on the neuronal and interkinetic nuclear migration of progenitor cells. A single intraperitoneal injection of BrdU was given at $3 \mathrm{~h}$ (at 5:00 P.M. on E13) after BDNF administration (at 2:00 P.M. on E13), and the brains were collected at 24, 36, 48, 60, 72, and $96 \mathrm{~h}$ after the BrdU injection (for neuronal migration) or at $3,7.5,9,10.5$, and $15 \mathrm{~h}$ after the BrdU injection (for interkinetic nuclear migration).

Phase-dependent effects of BDNF on the laminar fate of progenitors. A single injection of BrdU was performed at 5:00 P.M. on E13. Six hours before (at 11:00 A.M. on E13) or after (at 11:00 P.M. on E13) the injection, BDNF was injected intraventricularly (600 ng/embryo), and the brains were then collected at P6.

Dose-dependent effects of BDNF on the laminar fate of progenitor cells. A single injection of BrdU was given (at 5:00 P.M. on E13) $3 \mathrm{~h}$ after BDNF had been administered intraventricularly at various doses $(60,120,300$, or $600 \mathrm{ng} / \mathrm{embryo}$ ) on E13.5, and the brains were subsequently collected at P6.

Cumulative BrdU labeling. To determine the effect of BDNF on the overall length of the cell cycle $\left(\mathrm{T}_{\mathrm{C}}\right)$, the length of $\mathrm{S}\left(\mathrm{T}_{\mathrm{S}}\right)$, and the proportion of cells that were actively cycling, i.e., the growth fraction (GF), we performed cumulative BrdU labeling in E13.5 embryos by giving pregnant mice repeated intraperitoneal injections of $\mathrm{BrdU}(50 \mu \mathrm{g} / \mathrm{g})$, starting $3 \mathrm{~h}$ after BDNF or vehicle administration, at $2 \mathrm{~h}$ intervals between injections throughout a $24.5 \mathrm{~h}$ period. For each survival time, the last BrdU injection was given $0.5 \mathrm{~h}$ before death. The time for cell counting was 2.5, $4.5,6.5,8.5,10.5,12.5,16.5,20.5$, or $24.5 \mathrm{~h}$ after the initial BrdU injection (see Fig. 5A). The principles behind this method are as follows: (1) BrdU is incorporated into cells during the S-phase of the cell cycle, (2) continuously available $\mathrm{BrdU}$ is incorporated into previously unlabeled cycling cells as they pass from $G_{1}$ to $S$, and (3) consequently, the proportion of $\mathrm{BrdU}$-positive $\left(\mathrm{BrdU}^{+}\right)$cells per total number of ventricular zone cells [labeling index (LI)] increases over time. For estimating the total cell number, cell nuclei were stained with propidium iodide (PI) (Invitrogen, Carlsbad, CA). The maximum LI or growth fraction is attained when all of the cycling cells have passed into S-phase.

\section{BrdU and 5' -iodo-2' -deoxyuridine injection schedule}

To confirm the $\mathrm{T}_{\mathrm{S}}$, we performed sequential single intraperitoneal injections of $5^{\prime}$-iodo- $2^{\prime}$-deoxyuridine (IdU) and BrdU, starting $3 \mathrm{~h}$ after BDNF or vehicle administration. The principles of this method are as follow: ventricular progenitors are exposed to IdU at $t=0 \mathrm{~h}$ such that all cells in S-phase at the beginning of the experiment are labeled with IdU (see Fig. $5 B$ ). At $t=1.5 \mathrm{~h}$, cells are exposed to BrdU to label all cells in $\mathrm{S}$-phase at the end of the experiment [progenitor cells in the S-phase $\left.\left(\mathrm{P}_{\mathrm{S}}\right)\right]$. These cells will also be labeled with IdU, which is still present in the bloodstream. Animals are killed at $t=2 \mathrm{~h}$. Therefore, the interval during which cells can incorporate IdU but not $\operatorname{BrdU}\left(\mathrm{T}_{\mathrm{L}}\right)$ is $1.5 \mathrm{~h}$ (see Fig. $5 B$ ). During this time, cells in the initial IdU-labeled S-phase cohort will leave the S-phase at a constant rate. Consequently, this departing fraction will be labeled with IdU but not BrdU [progenitor cells leaving the S-phase $\left(\mathrm{P}_{\mathrm{L}}\right)$ ]. By staining tissue sections with monoclonal antibodies [mouse anti-IdU/BrdU antibody (Caltag Lab, Burlingame, CA); rat anti-BrdU antibody (Abcam, Cambridge, UK)], we can distinguish cells labeled with just IdU from those that incorporated BrdU and IdU (see Fig. 5B). The ratio of the length of any one period of the cell cycle to that of another period is equal to the ratio of the number of cells in the first period to the number in the second period (Nowakowski et al., 1989). Therefore, the ratio between the number of cells in the $P_{L}$ and the $P_{S}$ fractions is equal to the ratio between $\mathrm{T}_{\mathrm{L}}$ (which equals $1.5 \mathrm{~h}$ ) and $\mathrm{T}_{\mathrm{S}}: \mathrm{T}_{\mathrm{L}} / \mathrm{T}_{\mathrm{S}}=\mathrm{P}_{\mathrm{L}} / \mathrm{P}_{\mathrm{S}}$. That is to say, $\mathrm{T}_{\mathrm{S}}=\mathrm{T}_{\mathrm{L}} \times \mathrm{P}_{\mathrm{S}} / \mathrm{P}_{\mathrm{L}}=1.5 \times \mathrm{P}_{\mathrm{S}} / \mathrm{P}_{\mathrm{L}}$. Exactly the same analyses were performed by using with anti-BDNF chicken IgY antibody and normal chicken IgY.

\section{Pax6 expression}

We injected BrdU intraperitoneally into mice 3 h (at 5:00 P.M. on E13) after intraventricular administration of BDNF or vehicle (at 2:00 P.M. on E13) and collected brains 1, 3, 5, and $12 \mathrm{~h}$ after BrdU injection. Brain sections were prepared and double immunostained with specific antibodies against BrdU and Pax6 (paired box gene 6). We divided the $\mathrm{BrdU}^{+}$cells expressing Pax6 into two subgroups according to the intensity of their Pax6 reactivity. The $\mathrm{BrdU}^{+}$cells expressing prominent Pax6 
$\left(\mathrm{Pax}^{\mathrm{P}}{ }^{\mathrm{P}}\right.$ immunoreactivity in more than half of the nucleus were counted as $\mathrm{Pax}^{\mathrm{P}} / \mathrm{BrdU}^{+}$, and the rest of $\mathrm{BrdU}^{+}$cells regardless of expressing Pax6 immunoreactivity were counted as moderate Pax6 $\left(\operatorname{Pax}^{\mathrm{m}}\right)$ / $\mathrm{BrdU}^{+}$(see Fig. 7A).

\section{Quitting fraction}

To determine the number of cells leaving the cell cycle [quitting fraction ( $\mathrm{Q}$ fraction)], we gave mice a single intraperitoneal injection of $\mathrm{BrdU}$ at $3 \mathrm{~h}$ (at 5:00 P.M. on E13) after BDNF or vehicle administration (at 2:00 P.M. on E13) and then collected their brains at 12, 16, 20, and $24 \mathrm{~h}$ after BrdU administration. Subsequently, brain sections were prepared and immunostained with antibodies against BrdU and Ki67. The Q fraction was determined as the number of BrdU-positive and Ki67-negative cells in the BrdU-labeled population.

\section{Tissue preparation}

The animals were processed and analyzed as described previously (Fukumitsu et al., 1998; Ohmiya et al., 2002). Briefly, embryonic brains were fixed in $4 \%$ paraformaldehyde solution (fixative), and postnatal brains were removed after transcardial perfusion with the fixative and cut into 5-mm-thick slices, which were postfixed in the fixative. The brain tissues were soaked in PBS containing 20\% (w/v) sucrose and frozen in embedding compound (Sakura Finetek, Tokyo, Japan). Coronal serial sections $20 \mu \mathrm{m}$ thick were prepared with a cryostat (model CM 1800; Leica, Nussloch, Germany), attached to adhesive-coated slides (Matsunami, Osaka, Japan), and dried before being used for immunofluorescence studies.

\section{Immunohistological analysis}

Immunohistochemical analysis was performed as described previously (Fukumitsu et al., 1998; Ohmiya et al., 2002). Primary antibodies against calretinin (1:1000; Swant, Bellinzona, Switzerland), reelin (1:200; Millipore, Temecula, CA), Brn1 (neural specific POU-domain class III transcription factor also known as Pou3f3; 1:100; Santa Cruz Biotechnology, Santa Cruz, CA), Foxp2 (Forkhead box p2) (1:100; Santa Cruz Biotechnology), phosphohistone H3 (1:500 Upstate Biotechnology, Lake Placid, NY), TuJ1 (1:2000; Promega, Madison, WI), Hu C/D (1:200; Invitrogen), calbindin D-28K (1:2000; Sigma), Ki67 (1:50; DakoCytomation, Glostrup, Denmark), and Pax6 (1:1000; Millipore) were used. These primary antibodies were visualized with goat anti-mouse IgG conjugated to Alexa 488 or 546 (1:1000; Invitrogen) or with goat anti-rat IgG or donkey anti-goat IgG conjugated to Alexa 546 (1:1000; Invitrogen), and the fluorescence signals were observed with a confocal laser microscope (model LSM 510; Zeiss, Jena, Germany). For detection of the BrdU- and/or IdU-labeled cells, sections were treated with $2 \mathrm{~N} \mathrm{HCl}$ for $30 \mathrm{~min}$ at $37^{\circ} \mathrm{C}$ and $0.1 \%(\mathrm{w} / \mathrm{v})$ trypsin in PBS to unmask BrdU and/or IdU before being reacted with anti-BrdU [for single BrdU immunohistochemistry, with mouse (IgG) anti-BrdU, 1:1000 (Sigma); for IdU/BrdU double labeling, with rat (IgG) anti-BrdU, 1:100 (Abcam); and anti-IdU/BrdU antibody, 1:2000 (clone IU4, mouse IgG) (Caltag Lab), which recognizes both BrdU and IdU].

\section{In situ hybridization analysis}

In situ hybridization for marker-gene mRNAs was performed according to the method of Tole et al. (1997) with slight modifications. The stained sections were observed with an Axiovert S-100 microscope (Zeiss). The following riboprobes were used: those transcribed from murine cDNAs for mSorLA (nucleotides 5320-6101), ER81 (nucleotides 1197-1787) prepared by reverse transcription (RT)-PCR using total RNA obtained from P6 mouse brain, and those for ROR- $\beta$ (a gift from Dr. S. K. McConnell, Stanford University, Stanford, CA) and Cux1 (orthologue of the Drosophila cut gene) and Pax6 (gifts from Dr. A. Mansouri, MaxPlanck Institute, Göttingen, Germany).

\section{Semiquantitative studies on GFP-positive and BrdU-labeled cells} The distribution and number of $\mathrm{GFP}^{+}$and/or BrdU ${ }^{+}$cells were analyzed by focusing on the area of the dorsomedial cerebral wall overlying the medial region of the lateral ventricle and corresponding to the future primary somatosensory representation at the embryonic stages and on the somatosensory cortex at the postnatal stages. The sample size for analysis was $200 \mu \mathrm{m}$ (for embryos), $400 \mu \mathrm{m}$ (for P6 animals), or $1.0 \mathrm{~mm}$ (for P3W animals) in the mediolateral dimension, and $300 \mu \mathrm{m}$ (for embryos) or $500 \mu \mathrm{m}$ (postnatal animals) in the anteroposterior dimension. Within the anteroposterior dimension, the brain tissues were coronally sectioned at $20 \mu \mathrm{m}$ on a cryostat. The first and every third section (for embryos) or the first and every fifth section (for postnatal animals) were selected, and six sections per brain were examined. The whole cerebral cortex was evenly subdivided into 10 "sectors" that had an equal width and height along the ventricular lumen. The sectors were numbered from the ventricular surface outward. The number of $\mathrm{BrdU}^{+}$ and/or GFP ${ }^{+}$cells in each sector was counted and expressed as a percentage of the total number of each type of positive cell in the cortical area. $\mathrm{BrdU}^{+}$cell nuclei or $\mathrm{GFP}^{+}$cell bodies located at the boundary between two sectors were assigned to the sector closer to the ventricle. Positive nuclei or cell bodies located on medial or lateral boundaries were all counted, even if the diameters were smaller than their maximal ones. Endothelial cells were excluded from the count. For estimating the total cell number, cell nuclei were stained with PI (Invitrogen) and were counted in each sector by using the same criteria used for BrdU-positive cells. Experiments were performed at least three times with three to seven brains from two or three litters. For the semiquantitative studies of cumulative BrdU labeling and BrdU/IdU double labeling, we focused on the positive cells in the ventricular zone. The basal region of the VZ was distinguished from the adjacent subventricular zone (SVZ) by (1) the shape of the nuclei (elongated ellipsoid rather than nearly circular) and (2) their orientation (long axis vertical rather than oblique or horizontal). For analysis of the Q fraction, we separately calculated the score in the ventricular zone or in the whole area of the cerebral wall.

\section{Retrograde axon tracing}

P3W mice that had been treated with vehicle or BDNF and BrdU at E13.5 as described above were deeply anesthetized with sodium pentobarbital (30 $\mu \mathrm{g} / \mathrm{g})$. The skin of the head was incised at the midline, and 1-3 $\mu \mathrm{l}$ of $2 \%$ fast blue (FB) (Sigma), a retrograde tracer, was injected into the left side of the striatum [bregma, $-0.22 \mathrm{~mm}$; lateral, $2.0 \mathrm{~mm}$; vertical, 3.0 $\mathrm{mm}$ (according to the atlas of Paxinos and Franklin, 2001)] by using a glass micropipette guided by a Picospritzer II microinjector (General Valve, Fairfield, NJ). Ten days after the injection, the mice were processed as described under "Tissue preparation," and BrdU immunoreactivity was visualized in neurons of interest in tissue sections of the cerebral cortex. The fluorescence signals were observed microscopically (Axiovert S-100; Zeiss). We focused on cells double labeled with the FB retrograde tracer and BrdU.

\section{Semiquantitative RT-PCR}

Pregnant mice carrying day 13.5, 15.5, or 18.5 embryos were killed by an overdose of diethyl ether, and the embryonic cortices were taken from three to five embryos of each age, as were the cortices from the dames, and used for semiquantitative RT-PCR analysis. Semiquantitative RTPCR was performed as described previously (Ito et al., 2003). The numbers of PCR cycles were optimized to be in the linear range of amplification by using specific $\beta$-actin primers. The following primer sets were used: $\beta$-actin, $5^{\prime}$-GTGGGCCGCTCTAGGCACCAA- $3^{\prime}$ and $5^{\prime}$-CTCTT TGATATCACGCACGAT-3'; BDNF, $5^{\prime}$-GGAATTCGAGTGATGACCA TCCTTTTCCTTAC- $3^{\prime}$ and $5^{\prime}$-CGGATCCCTATC TTCCCCTTTTAA TGGTCAGTG-3'; and TrkB, 5' -CCAAGCCTGCGCTTCAGTGGTT-3' and $5^{\prime}$-TCACAGGGCGTCAGGCAACAAG- ${ }^{\prime}$. An aliquot of the PCR products was resolved by agarose gel electrophoresis and visualized by ethidium bromide staining. The intensity of the bands was analyzed by use of image-analysis software (NIH ImageJ).

\section{Statistical analyses}

Statistical comparisons were made by using Student's $t$ test for unpaired data. Because the sample size was small, a resampling method $(10,000$ iterations) was used to adjust $p$ values. ANOVA was performed with Tukey's post hoc test to establish significance. 
A

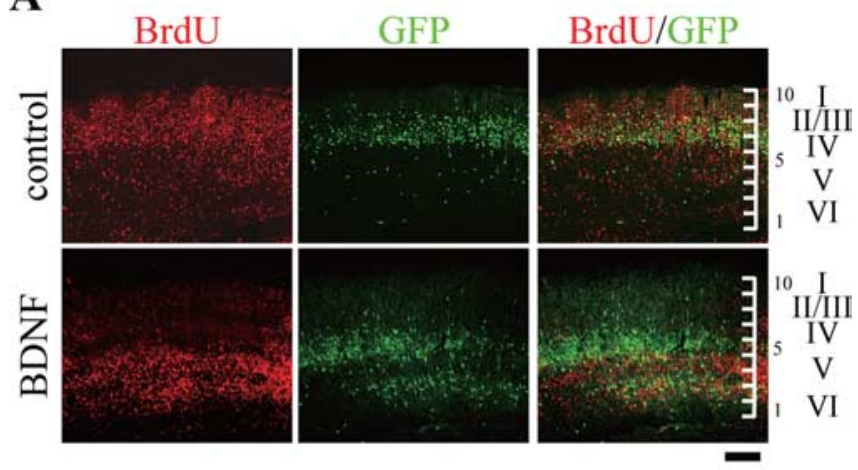

B

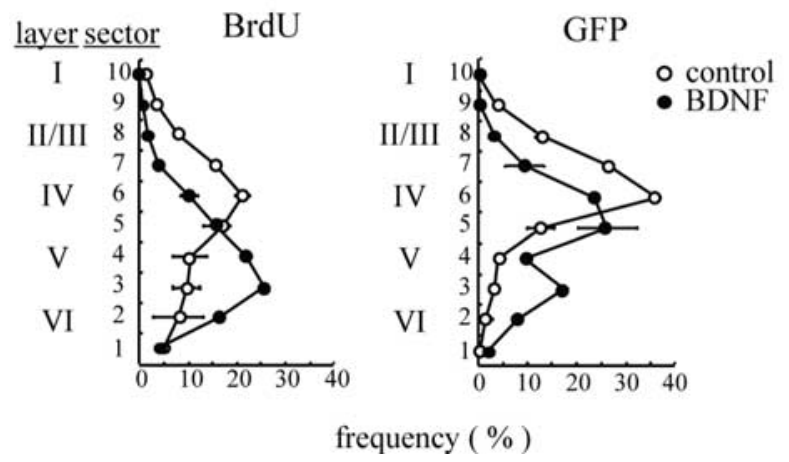

Figure 1. BDNF influences migration of cortical neurons generated from E13.5 progenitors. Immediately after electroporation of pCAG-hrGFP that had been microinjected into the ventricular space of E13.5 mouse embryos, BDNF or vehicle was injected into the same ventricular space. The uterus bearing the embryos was then returned to the abdominal cavity. The pregnant mice were given a single injection of BrdU ( $50 \mu \mathrm{g} / \mathrm{g}$ body weight, i.p.) $3 \mathrm{~h}$ after BDNF/ vehicle administration to label mitotic progenitors in the embryonic brains. After birth, the pups were fed for 3 weeks to examine cell migration. $A$, Fluorescent images of BrdU ${ }^{+}$cells or GFP ${ }^{+}$ cells and merged images showing cells with both labels. The majority of BrdU ${ }^{+}$or GFP ${ }^{+}$cells were located at layer IV in vehicle-treated animals, but most of the BrdU ${ }^{+}$cells and a part of the $\mathrm{GFP}^{+}$cells were located at layers V and VI in the BDNF-treated animals. Scale bar, $200 \mu \mathrm{m} . \boldsymbol{B}$, The percentage of $\mathrm{BrdU}^{+}$or GFP ${ }^{+}$cells in each sector is expressed as the mean $\pm \mathrm{SE}$. The SE is not shown when it is less than the width of the symbols. In BDNF-treated animals, the proportion of cells migrating to layers $V$ and $V I$ among the cells with each type of label was significantly higher than that in the vehicle-treated animals $\left(67.9 \pm 0.8 \mathrm{vs} 33.1 \pm 0.8 \%\right.$ for BrdU ${ }^{+}$cells and $37.0 \pm 2.1$ vs $8.5 \pm 1.9 \%$ for GFP ${ }^{+}$cells; $p<0.0005$, and $p<0.005$, respectively, Student's $t$ test $n=4)$.

\section{Results}

Alteration of the positioning of cortical neurons

To determine the distributions of the generated cells, we labeled the progenitors with the GFP expression vector pCAG-hrGFP and BrdU on E13.5 and examined them at P3W with a confocal laser microscope (Fig. 1). The greatest numbers of $\mathrm{BrdU}^{+}$and $\mathrm{GFP}^{+}$cells were observed in sector 6 , corresponding to layer IV of the cerebral cortex, in the vehicle-injected animals. However, in BDNF-treated animals, most of the $\mathrm{BrdU}^{+}$cells were localized in sector 3, corresponding to layers V and VI, and dual peaks of $\mathrm{GFP}^{+}$cells were observed in sectors 5 and 3, equivalent to layer IV and layers V and VI, respectively. It was obvious that a substantial number of neurons positive for BrdU or GFP or both (BrdU/GFP) were distributed in layers V and VI in the addition to layer IV of the BDNF-treated cerebral cortex. The proportion of cells migrating to deeper layers was higher among $\mathrm{BrdU}^{+}$cells than among $\mathrm{GFP}^{+}$cells, probably attributable to the difference in
A

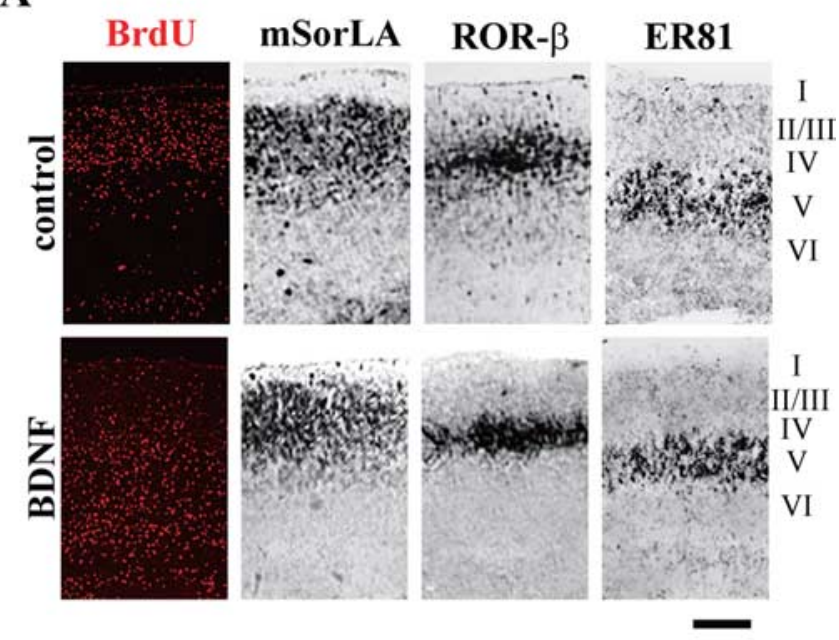

B
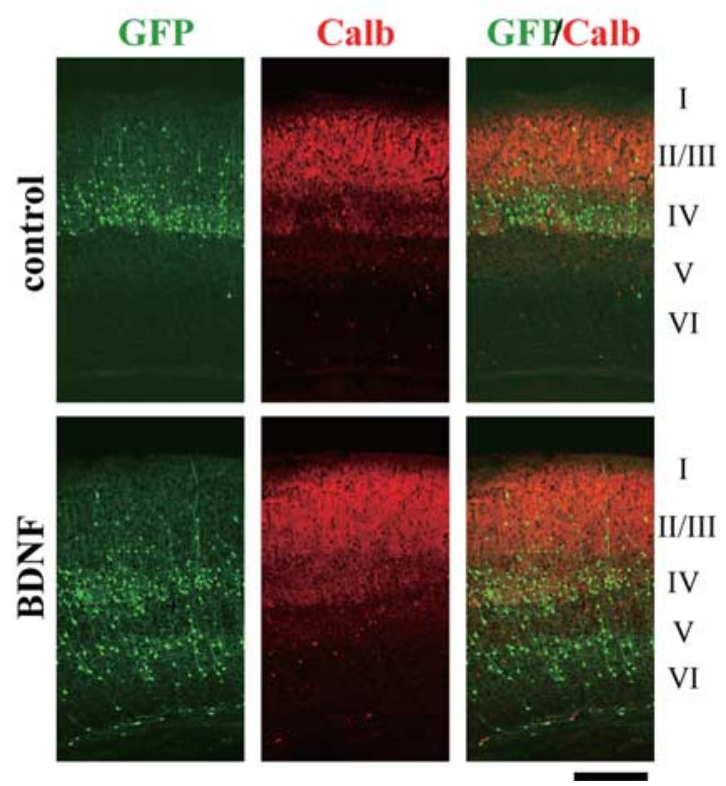

Figure 2. Postnatal laminar organization is normal after BDNF treatment of E13.5 progenitors. $\boldsymbol{A}$, Expression of layer-specific mRNAs (mSorLA, ROR- $\beta$, and ER81) in the cerebral cortex of a P6 mouse was analyzed by in situ hybridization after administration of BDNF protein (bottom) or vehicle (top) at E13.5. Mitotic neural progenitors were labeled with BrdU injected intraperitoneally into pregnant mother mice. BDNF altered the destination of BrdU-labeled neurons so that they occupied much deeper layers, but it did not alter the distribution of layer-specific mRNA. $\boldsymbol{B}$, Expression of calbindin D-28K (Calb) protein in the cerebral cortex of a P3W mouse treated with BDNF (bottom) or vehicle (top) atE13.5. pCAG- hrGFP plasmid was electroporated into progenitors of the VZ immediately before injection of BDNF or vehicle. The highly ordered lamination was still maintained even in the cerebral cortex of the BDNF-treated mouse, as judged by the strength of calbindin D-28K expression observed in inhibitory neurons of layers II-VI and the weakness of its expression in neurons of layers II and III. Scale bars, $200 \mu \mathrm{m}$.

the principle of the methods used for labeling the cells. That is, plasmids can be introduced into all progenitors facing the ventricular surface, regardless of the phase of the cell cycle, whereas BrdU is incorporated only into cells in the S-phase of the cell cycle.

Layer-specific gene expression in neurons with altered destination

We next characterized the $\mathrm{BrdU}^{+} / \mathrm{GFP}^{+}$neurons that migrated to layers V and VI, deeper layers than expected. Each layer spe- 
cifically expresses a particular gene from among ER81 [layer V (Hevner et al., 2003)], ROR- $\beta$ [layer IV (Becker-Andre et al., 1994)], or mSorLA [layer II/III (Hermans-Borgmeyer et al., 1998)]. The expression profiles of these genes (Fig. 2A) and the laminar organization of layers II/ III as judged from the expression of calbindin D-28K (Fig. $2 \mathrm{~B}$ ) were essentially the same in vehicle- and BDNF-treated cortices. That is, BDNF caused no gross abnormality in the pattern of cortical lamination. In addition, no changes were observed in the number of PI-positive cells that composed each sector (data not shown) or in the total number of BrdUpositive cells in layers I-VI or in the white matter (Table 1). These data suggest that the $\mathrm{BrdU}^{+} / \mathrm{GFP}^{+}$neurons in the deeper layers had gained the gene expression and properties specific to neurons of the deeper layers rather than those of the layer IV neurons, which would otherwise have been expected. To confirm this result, we visualized both BrdU and layer-specific proteins such as Brn1 for layers II/III (McEvilly et al., 2002) and Foxp2 for layer VI (Ferland et al., 2003) (Fig. 3A). Substantial numbers of BrdU ${ }^{+}$cells expressed Brn1, but few $\mathrm{BrdU}^{+}$cells expressed Foxp2 in the vehicle-treated cortex (Fig. $3 B$, Table 1). In contrast, in BDNF-treated mice, the $\mathrm{BrdU}^{+}$cells expressing Foxp2 were significantly increased in number; whereas those expressing Brn1 were decreased in number (Fig. $3 B$, Table 1). We also tested whether the destination-altered $\mathrm{BrdU}^{+}$neurons projected their axons into the layer-specific targets. The retrograde tracer FB was injected into the striatum, one of the axonal targets of layer $\mathrm{V}$ neurons, in vehicle- or BDNF-treated mice at P3W, and FB fluorescence was then chased in the BrdU-labeled neurons. Substantial numbers of FB-labeled neurons were scattered throughout layer $\mathrm{V}$ regardless of BDNF treatment. More than $80 \%$ of FBlabeled neurons in layer $\mathrm{V}$ were also labeled with BrdU in BDNF-treated brains, but $<20 \%$ of these FB-labeled cells were labeled with BrdU in vehicle-treated brains (Fig. 3C). These observations demonstrate that the $\mathrm{BrdU}^{+}$neurons that had migrated ectopically to deeper layers as a result of BDNF treatment had gained the axonal projection properties corresponding to the deeper layers they had migrated to and suggest that BDNF regulated the laminar fate of neurons newly generated from neural progenitors in addition to their migration destination.

\section{Cell migration}

Next we examined the behavior of $\mathrm{BrdU}^{+} / \mathrm{GFP}^{+}$cells in the intermedial cortical zone (ICZ) after BDNF administration on

A

B mice. Scale bars, $200 \mu \mathrm{m}$.
Table 1. Effect of BDNF on the laminar fate of the BrdU-positive cells

\begin{tabular}{|c|c|c|c|c|c|c|}
\hline \multirow[b]{2}{*}{ Injection } & \multicolumn{4}{|l|}{ Cell number } & \multicolumn{2}{|c|}{ Ratio of positive cells (\%) } \\
\hline & $\mathrm{Brn}^{+}$ & Foxp2 ${ }^{+}$ & $\mathrm{BrdU}^{+}(\mathrm{ly}|-V|)$ & $\mathrm{BrdU}^{+}(\mathrm{wm})$ & $\mathrm{Brn}^{+} / \mathrm{BrdU}^{+}$ & $\mathrm{Foxp}^{+} / \mathrm{BrdU}^{+}$ \\
\hline Vehicle & $629.1 \pm 3.4$ & $380.4 \pm 3.7$ & $177.4 \pm 11.8$ & $47.8 \pm 2.1$ & $28.0 \pm 1.7 \%$ & $7.9 \pm 0.5 \%$ \\
\hline BDNF & $627.0 \pm 13.1$ & $376.9 \pm 6.3$ & $174.0 \pm 13.7$ & $47.8 \pm 2.9$ & $13.3 \pm 1.4^{* * *}$ & $17.0 \pm 1.3^{* * *}$ \\
\hline BDNF ab & $564.2 \pm 8.6^{* * *}$ & $377.0 \pm 4.9$ & $203.3 \pm 8.2^{*}$ & $46.0 \pm 1.6$ & $65.0 \pm 7.1^{* *}$ & $4.4 \pm 0.6^{*}$ \\
\hline
\end{tabular}
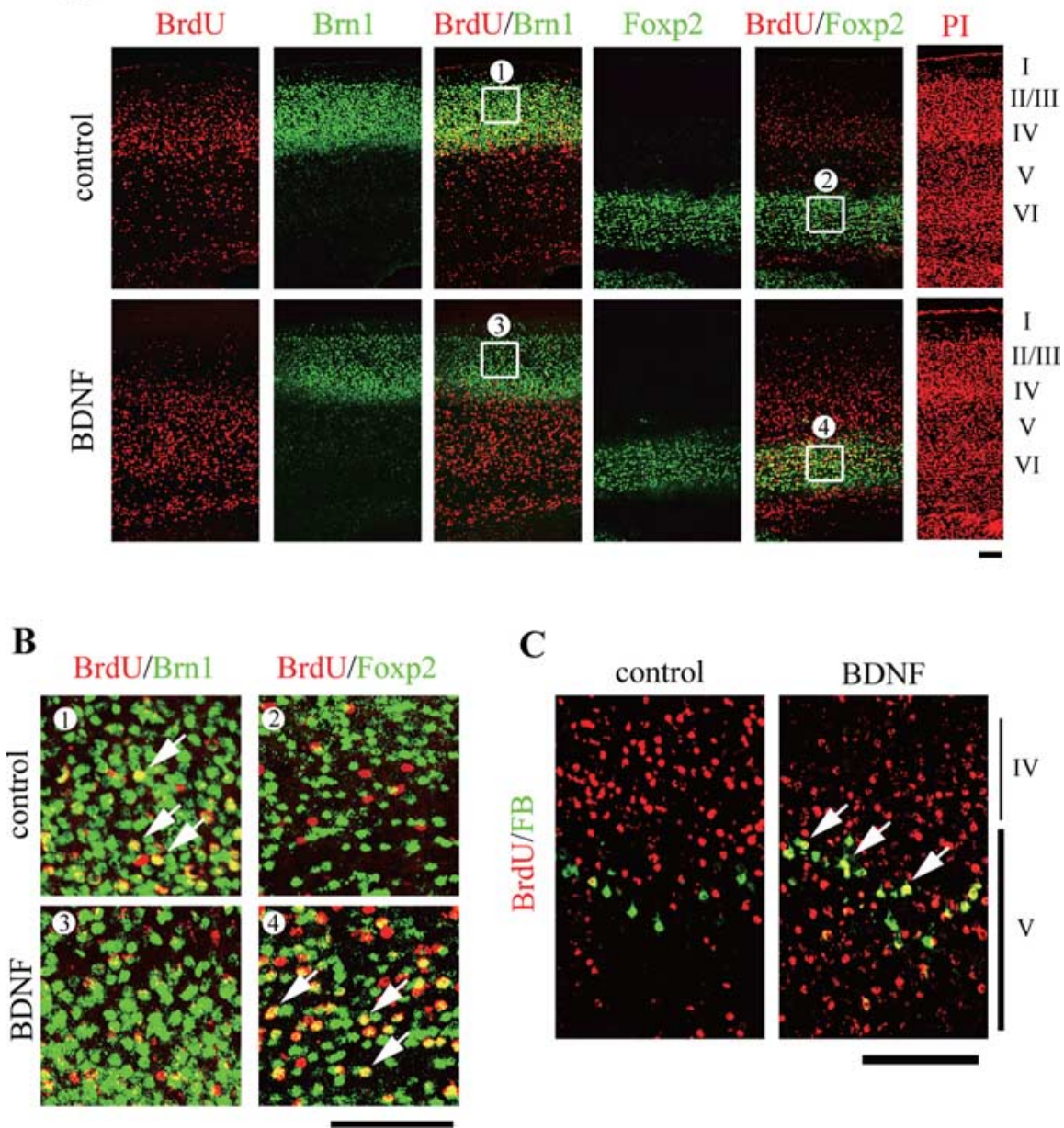

C
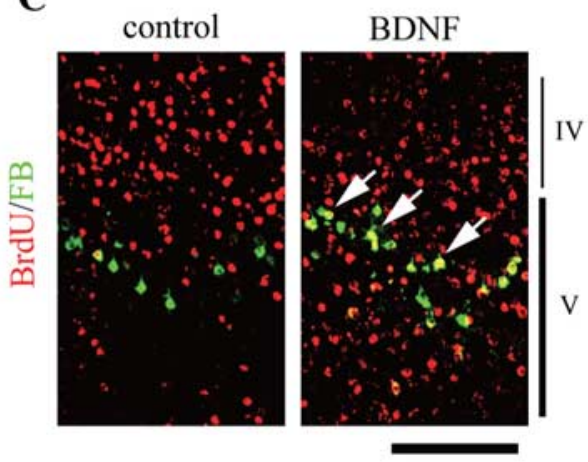

Figure 3. Layer-dependent gene expression in neurons generated from BDNF-treated neural progenitors. $A, P 6$ mouse cerebral cortex that had been treated with BDNF at E13.5 was double immunostained with anti-BrdU antibody (red) and antibody against layer-specific markers (green; Brn1 for layer II/III and Foxp2 for layer VI). The expression profiles of Brn1 and Foxp2 were indistinguishable between BDNF-treated and control tissues, although BrdU-positive cells had substantially migrated to the deeper layers as a result of the BDNF treatment. $\boldsymbol{B}$, Enlarged views of the boxed areas shown in $\boldsymbol{A}$. Vehicle-treated cortex (control) contained substantial numbers of BrdU ${ }^{+} / \mathrm{Brn1}^{+}$cells (short arrows in 1) but hardly any BrdU ${ }^{+} /$Foxp2 ${ }^{+}$cells (2). In contrast, $\mathrm{BrdU}^{+} /$Foxp2 ${ }^{+}$cells had increased in number in the BDNF-treated cerebral cortex (short arrows in 4), but no Brn ${ }^{+} /$BrdU $^{+}$cells (3) were detected. C, Layer V neurons projecting their axons into the striatum. FB was injected into the striatum of P3W mice that had been treated with BDNF or vehicle on E13.5, and FB fluorescence was chased in BrdU-labeled neurons for $10 \mathrm{~d}$. Few FB-positive cells were BrdU ${ }^{+}$in the vehicle-treated mice, but increased numbers of $\mathrm{FB}^{+} / \mathrm{BrdU}^{+}$cells were observed in the BDNF-treated

E13.5. Observations on E15.5 demonstrated that most of the $\mathrm{BrdU}^{+} / \mathrm{GFP}^{+}$cells in the vehicle-treated mice were located in the VZ, SVZ, or lower half of the intermediate zone (IZ) and that the numbers of $\mathrm{BrdU}^{+} / \mathrm{GFP}^{+}$cells in BDNF-treated animals were increased in the areas from the upper half of the IZ to the CP but decreased in the VZ (Fig. $4 A$ ). In both control and BDNF-treated cortices, the GFP ${ }^{+}$cells in the SVZ and in the middle and lower areas of the IZ had a highly multipolar shape, whereas those distributed within the upper region of the IZ, just below the CP, 
A

E13.5-15.5

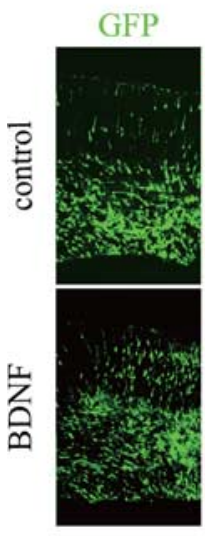

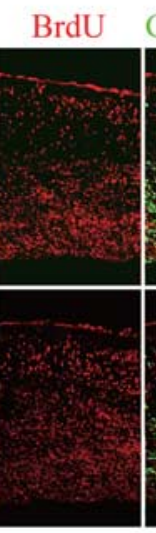

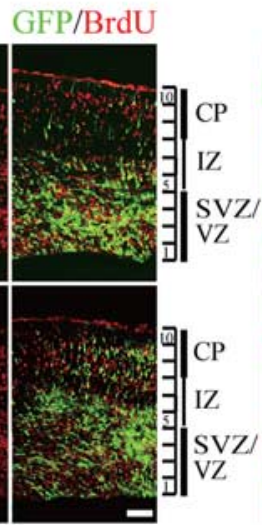

E13.5-17.5

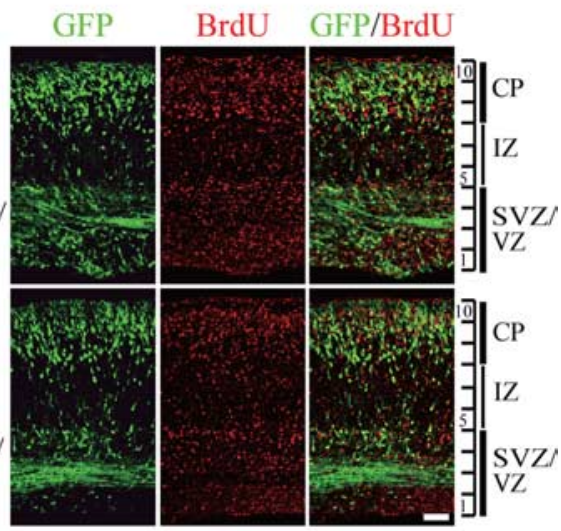

B

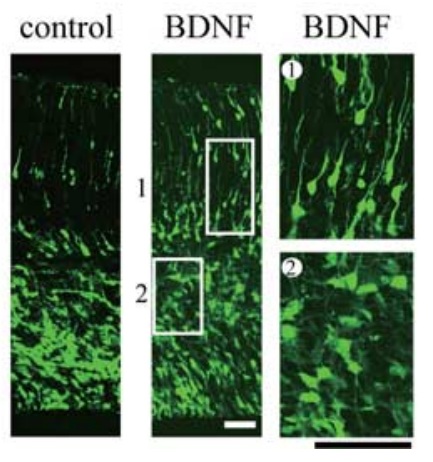

C

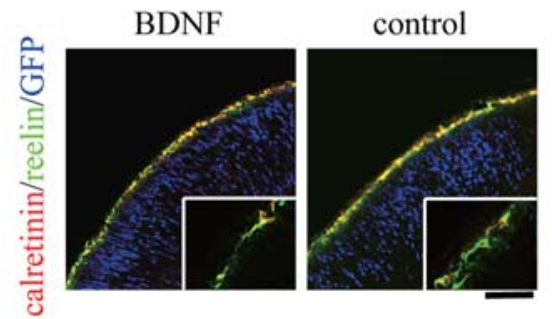

Figure 4. Migration machinery is essentially not influenced by BDNF. $A, \mathrm{GFP}^{+}$and/or BrdU ${ }^{+}$cells in the cerebral cortex visualized $2 \mathrm{~d}$ (left, E15.5) or $4 \mathrm{~d}$ (right, E17.5) after BDNF or vehicle administration on E13.5. On E15.5, both types of positive cells had increased in number in areas from the upper half of the IZ to the CP and decreased in the VZ in the BDNF-treated animals. On E17.5, most of both types of positive cells had reached the CP regardless of BDNF treatment. Scale bars, $100 \mu \mathrm{m}$. $\boldsymbol{B}$, Typical morphologies of migrating cells normally observed in both BDNF- and vehicle-treated cerebral cortex. Number 1 shows GFP ${ }^{+}$ cells between the superficial part of the $I Z$ and the $C P$ that exhibit a radially oriented bipolar cell body with a heavy apical process, and 2 shows GFP ${ }^{+}$cells between SVZ and the lower IZ that have cell bodies with multipolar processes. Scale bars, $100 \mu \mathrm{m}$. $\boldsymbol{C}$, Typical morphology and reelin expression of $C R$ neurons were normal in both BDNF- and vehicle-treated cerebral cortex. Enlarged views of the boxed areas are shown as insets in each figure. Scale bars: overviews, $50 \mu \mathrm{m}$; enlarged views, $200 \mu \mathrm{m}$.

had radially oriented bipolar shapes (Fig. $4 B$ ). Moreover, additional detailed analysis of distributional changes in migrating $\mathrm{BrdU}^{+}$cells revealed that many of these cells exited from the sectors 1 and 2, corresponding to the lower ventricular zone from 12 until $36 \mathrm{~h}$ after the BrdU injection, stayed at sectors 4 and 5, corresponding to upper ventricular zone and subventricular zone from 24 to 60 after BrdU injection, and migrated toward sectors 9 and 10, equivalent to the $\mathrm{CP}$ afterward in both control and BDNF-treated cortices (supplemental Fig. 1, available at www. jneurosci.org as supplemental material). These sequential changes were seen in both cases and tended to proceed slightly faster in the BDNF-treated cortex than in the control one, although there was no statistically significant difference. Together with the lack of morphological and behavioral differences in the migrating cells in vehicle- and BDNF-treated animals, these results demonstrate that the migration machinery was essentially unaffected by the BDNF treatment.

Ringstedt et al. (1998) reported that overexpression of BDNF by transgenic methods induced heterotopic aggregation of and reduced reelin production by $\mathrm{CR}$ neurons with accompanying cortical laminar disorganization. However, the intraventricular administration of BDNF did not induce such characteristic changes in CR neurons (Fig. 4C), in agreement with other previous studies. That is, in previous studies, no aggregation of CR neurons was found in the cortex, although these authors did not examine the expression of reelin in these neurons [2.9 $\mu \mathrm{g} \mathrm{BDNF/embryo} \mathrm{(Brunstrom} \mathrm{et} \mathrm{al.,}$ 1997); 700 ng BDNF/embryo (Ohmiya et al., 2002)]. Probably, the amount of BDNF that penetrated into the CP would not have been enough to induce such phenotypes in CR neurons. Therefore, the alteration of laminar fate brought about by BDNF might not have been mediated by CR neurons via their synthesis of reelin.

\section{Precocious neurogenesis through} accelerated completion of S-phase accompanied by interkinetic migration Because the migratory machinery was essentially not affected by BDNF treatment, we next analyzed the cell-cycle parameters and the interkinetic nuclear migration of cortical progenitors in the VZ. Cumulative BrdU labeling of the E13.5 cortex revealed that the $\mathrm{T}_{\mathrm{S}}$ of the ventricular progenitors was shorter in the BDNF-treated cortex than in the control one (Fig. 5A, Table 2). The $\mathrm{T}_{\mathrm{S}}$ was also confirmed by adaptation of BrdU/IdU double-labeling paradigms (Fig. $5 B$ ). Moreover, the $\mathrm{T}_{\mathrm{C}}-\mathrm{T}_{\mathrm{S}}$ and the fraction of dividing cells, also referred to as the growth fraction, were not altered by the BDNF administration (Table 2). Therefore, BDNF did not increase the number but would accelerate the timing of cells exiting from the cell cycle by precocious completion of the S-phase. To confirm this matter, we examined the ratio of cells leaving the cell cycle ( $Q$ fraction). The $\mathrm{Q}$ fraction increased $12 \mathrm{~h}$ after the BrdU injection and entered its plateau by $24 \mathrm{~h}$ in both the $\mathrm{VZ}$ and the whole cortical area. This increase was observed in both the vehicle- and BDNF-treated cortices, but the ratio was slightly but significantly greater in the BDNF-treated cortex than in the vehicle-treated one at early times after the injection (Table 3 ).

In general, interkinetic nuclear migration is associated with neurogenesis and proceeds in the following sequence: (1) downward translocation to the ventricular surface in $S-$ to $G_{2} / M$-phase and mitosis; (2) upward translocation in the $G_{1}$-phase of a daughter cell, which reenters the cell cycle for proliferation; and (3) migration of the other daughter cell, which exits from the cell cycle (arrested in $\mathrm{G}_{0}$-phase) and moves up to the $\mathrm{CP}$ as a postmitotic neuron (Fujita, 1963).

In BDNF-treated mice, $\mathrm{BrdU}^{+}$nuclei had primarily accumulated at the ventricular surface (sectors 1 and 2) during the period of 7.5-9 h after the introduction of BrdU, and, by $10.5 \mathrm{~h}$, some of the $\mathrm{BrdU}^{+}$nuclei were in the process of migrating to the upper sectors (3-10), suggesting that, by $10.5 \mathrm{~h}$, most of the cells with $\mathrm{BrdU}^{+}$nuclei had already passed through $\mathrm{M}$-phase and were 
changing their position to the upper side (i.e., the basal area) of the VZ (Fig. 6A, $B$ ) (more detail in supplemental Fig. 2, available at www.jneurosci.org as supplemental material). These processes occurred a few hours later in the vehicle-treated mice, i.e., a similar accumulation of $\mathrm{BrdU}^{+}$nuclei at the ventricular surface was observed from $10.5 \mathrm{~h}$ after the BrdU injection (Fig. $6 \mathrm{~B}$ ). The peak of accumulation of $\mathrm{BrdU}^{+}$cells at the ventricular surface of the control mice was delayed from the expected time, i.e., summed $\mathrm{T}_{\mathrm{S}}$ and $\mathrm{T}_{\mathrm{G} 2+\mathrm{M}}$. This lag time might have been caused for the following reasons: (1) rates of upward nuclear translocation is slower than those of downward translocation; indeed $\mathrm{T}_{\mathrm{G} 1}$ is five to six times longer than $\mathrm{T}_{\mathrm{G} 2+\mathrm{M}}$; (2) after completion of cell division (at M-phase), $\mathrm{BrdU}^{+}$cells are twofold greater in the number; (3) nuclei of the mitotic cells are completely labeled with BrdU without space between 0.5 and $2 \mathrm{~h}$ after the BrdU injection but partially, hereinafter until $5 \mathrm{~h}$ (Takahashi et al., 1995); therefore, at least a $2-5$ h delay in accumulation could occur for this third reason only. These observations are consistent with those of a former report, i.e., the accumulation of $\mathrm{BrdU}^{+}$ cells was observed in the cortex at $10 \mathrm{~h}$ after intraperitoneal BrdU injection on E14 mice (Hatta et al., 2002). Phosphohistone $\mathrm{H} 3$ staining confirmed that mitosis occurred solely at the luminal surface in both BDNF- and vehicle-treated animals in this experimental model (Fig. 6C). Moreover, $\mathrm{Hu}^{+}$(data not shown) and/or $\mathrm{TuJ}^{+}$neurons were distributed from the IZ to the CP, but not in the VZ, in both BDNF- and vehicletreated animals, indicating that heterotopic neurogenesis did not occur in the BDNF-treated cortex (Fig. 6C). Therefore, BDNF accelerated the completion of the S-phase and caused faster interkinetic nuclear migration, an effect that may have advanced exit from the cell cycle or neurogenesis.

\section{Transient downregulation of Pax6 expression}

Neurogenesis was accelerated for only a few hours, which is not likely the sole reason for laminar fate alteration of the progenitors. To test the possibility that BDNF would directly reprogram their laminar fate, we investigated the expression of Cuxl, the transcription factor predominantly expressed in the progenitors committed to generate upper-layer neurons before terminal mitosis (Nieto et al., 2004), and the expression of Pax6 as a complementary marker (Gotz et al., 1998). Consistent with previous reports, the mRNAs of Cux1 and Pax6 were prominently expressed in the SVZ and VZ, respectively, although both transcripts were expressed in the SVZ/VZ. The general distribution patterns of these genes essentially remained constant at 3-12 h after BDNF administration (data not shown). Therefore, no dramatic change such as loss of expression of the Cux1 was induced by BDNF administration. To clarify in more detail the effect of BDNF on the expression profile of genes involved in the interkinetic migration of progenitors, we performed double labeling
B
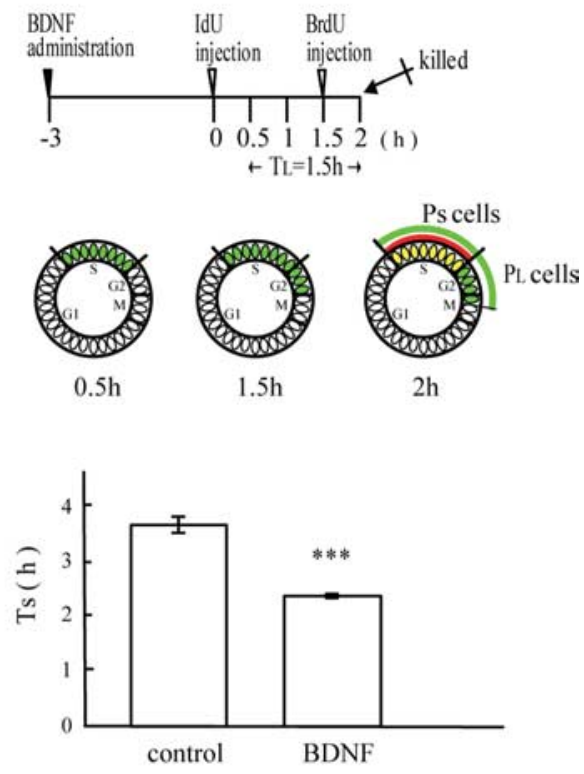

Figure 5. BDNF accelerates completion of S-phase of cortical progenitors without affecting other cell-cycle parameters. $\boldsymbol{A}$, 列 列 $x$-axis gives $T_{C}-T_{S}$. $T_{S}$ is given by the projection of $L I=0$ on the $x$-axis. The $\mathrm{T}_{C}-\mathrm{T}_{S}$ value is similar under the two conditions. The $\mathrm{T}_{\mathrm{s}}$ value is reduced in BDNF-administered cortex compared with that for the vehicle-treated cortex. The regression coffients obtained from the nonlinear fit were the following: vehicle, $2-12 \mathrm{~h}$ time points, $r^{2}=0.9874 ; \mathrm{BDNF}, 2-12 \mathrm{~h}$ time method. IdU was injected to label all cells in S-phase at $3 \mathrm{~h}$ after BDNF or vehicle administration on E13.5 $(t=0 \mathrm{~h})$. At $t=1.5 \mathrm{~h}$, an inection of BrdU was given, and the embryos were then fixed after a short survival period of $0.5 \mathrm{~h}$ (progenitors in cohort left the $S$-phase and consequently were labeled just with IdU; this is the departing fraction (progenitors leaving from S-phase, or $P_{L}$ ). $T_{S}$ was calculated by $1.5 \times P_{S} / P_{L}$. Values are expressed as means $\pm S E$ of the $T_{S}$ in the bottom. ${ }^{* * *} p<0.0005$ (Student's $t$ test; $n=3$ ).

Table 2. Effects of BDNF on cell-cycle parameters of ventricular progenitors

\begin{tabular}{lllll}
\hline \multirow{5}{*}{ Injection } & \multicolumn{4}{l}{ Cell-cycle parameters } \\
\cline { 2 - 5 } & $\mathrm{T}_{\mathrm{C}}-\mathrm{T}_{\mathrm{S}}$ & $\mathrm{T}_{\mathrm{S}}$ & $\mathrm{T}_{\mathrm{C}}(\mathrm{h})$ & $\mathrm{GF}(\% \pm \mathrm{SD})$ \\
\hline Vehicle & 12.4 & 3.3 & 15.7 & $97.4 \pm 1.2$ \\
BDNF & 12.1 & 2.3 & 14.4 & $97.7 \pm 1.0$ \\
\hline
\end{tabular}

Details were described in Results. All of the parameters were estimated by cumulative BrdU-labeling analysis. The mean of the values of $\mathrm{LI}$ at 20.5 and $24.5 \mathrm{~h}$ was used as the GF.

Table 3. Effect of $B D N F$ on the $Q$ fraction of $\mathrm{BrdU}^{+}$cells

\begin{tabular}{llllll}
\hline & & \multicolumn{4}{l}{ The ratio of Q fraction of BrdU-positive cells (\%) } \\
\cline { 3 - 6 } Injection & Area & 12 & 16 & 20 & $24(\mathrm{~h})$ \\
\hline Vehicle & VZ & $14.1 \pm 0.1$ & $31.7 \pm 0.3$ & $37.4 \pm 1.4$ & $40.1 \pm 0.5(\%)$ \\
BDNF & VZ & $14.9 \pm 0.2^{*}$ & $33.1 \pm 0.8^{*}$ & $39.4 \pm 1.5$ & $40.3 \pm 1.0(\%)$ \\
Vehicle & Total & $21.6 \pm 0.5$ & $42.8 \pm 1.0$ & $59.1+1.7$ & $68.4+1.3(\%)$ \\
BDNF & Total & $24.0 \pm 0.5^{*}$ & $47.9 \pm 1.5^{*}$ & $63.4 \pm 1.1$ & $69.1 \pm 0.3(\%)$ \\
\hline
\end{tabular}

Single intraperitoneal injection of BrdU was performed $3 \mathrm{~h}$ after BDNF or vehicle administration, and then the brains were collected 12, 16, 20, and $24 \mathrm{hr}$ after BrdU injection. The brain sections were double immunostained with antibodies against BrdU and Ki67. The $\mathrm{Q}$ fraction in the VZ or in the whole cortex (Total) was determined as ratio (percentage) of the number of Ki67-negative/BrdU ${ }^{+}$cells to the number of total $\mathrm{BrdU}^{+}$cells. The values are expressed as the mean \pm SE. ${ }^{*} p<0.05$, Student's $t$ test; $n=3$.

with both BrdU and Pax6 antibody, because recent studies suggest that Pax6 is a multifunctional transcription factor essential for specification of upper-layer glutamatergic neurons (Schuurmans et al., 2004). Consistent with previous reports, close to 
A

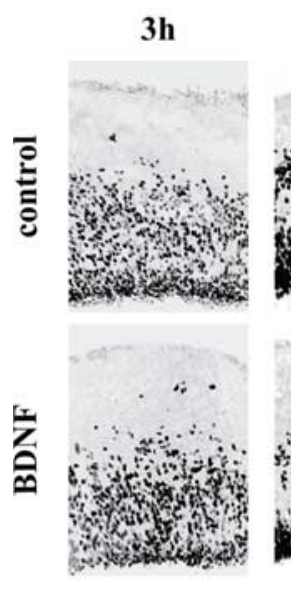

$7.5 \mathrm{~h}$
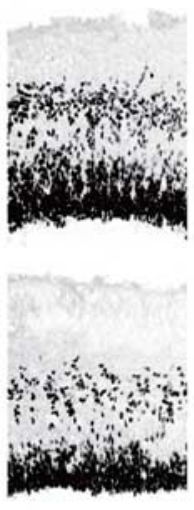

9h

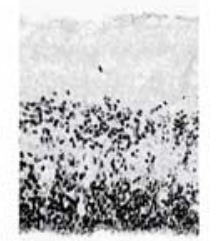

10.5h
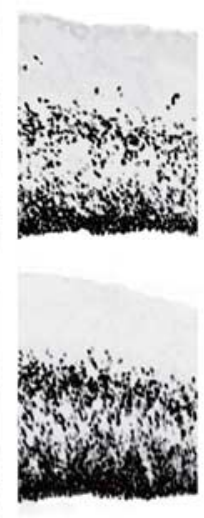

C

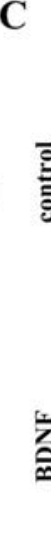

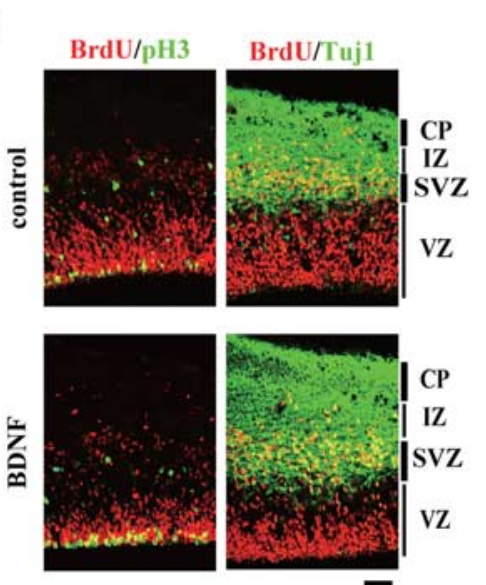

Figure 6. BDNF facilitates interkinetic migration of cortical progenitors. BDNF (600 ng in $2 \mu$ l of PBS) was administered into the ventricular space of 13.5 mouse embryos $3 \mathrm{~h}$ after the injection of BrdU into pregnant mice. $\boldsymbol{A}$, BrdU immunostaining patterns in the cerebral cortex at $3,7.5,9,10.5$, and $15 \mathrm{~h}$ after the injection. Interkinetic migration occurred normally even after BDNF administration, but the process was accelerated by BDNF. Scale bar, $50 \mu \mathrm{m} . \boldsymbol{B}$, Quantitative analysis of the distribution of BrdU ${ }^{+}$ nuclei. The number of positive nuclei remaining in upper sectors (sectors 3-10) is expressed as a percentage of the total number of BrdU ${ }^{+}$nuclei. Significant differences from the corresponding control (no treatment with BDNF) were determined by ANOVA with Tukey's post hoc test. ${ }^{*} p<0.05,{ }^{* *} p<0.01(n=5)$. C, Double immunostaining for BrdU and phosphorylated histone $\mathrm{H} 3$ or TuJ1 $9 \mathrm{~h}$ after the BrdU injection. Scale bar, $50 \mu \mathrm{m}$.

$100 \%$ of the cells in the VZ were immunopositive for Pax6, whereas many cells were Pax6 negative in the SVZ of both control and BDNF-treated mice (Fig. 7A). However, the number of $\mathrm{BrdU}^{+}$cells expressing a prominent level of Pax6 (Pax6 ${ }^{\mathrm{P}} /$ $\mathrm{BrdU}^{+}$) was reduced at 3 and $5 \mathrm{~h}$ after BrdU injection and recovered to nearly original level at $12 \mathrm{~h}$ (Fig. $7 A, B$ ). This temporal reduction of Pax6 expression on the $\mathrm{BrdU}^{+}$cells was promoted by BDNF administration and was preceded by accelerated interkinetic migration (Fig. $7 C$ ). These results indicate that BDNF temporarily reduced the Pax6 expression on the progenitor cells in their S- and/or S- to $\mathrm{G}_{2} / \mathrm{M}$-phase transition.

\section{Quantification of biological action and clearance rate of exogenous BDNF}

It is important to know the dose responsiveness and clearance rate of exogenous BDNF. The effects of BDNF on neuronal migration were observed to be dose dependent when $>120 \mathrm{ng}$ of BDNF was applied (Fig. $8 \mathrm{~A}$ ). That is, the minimal dose necessary for dose-dependent activity was $120 \mathrm{ng}$ /injection. To determine the clearance rate, we measured the BDNF content in the brain after intraventricular injection of $600 \mathrm{ng}$ by a sensitive and reliable enzyme immunoassay for BDNF (Nitta et al., 1999). The BDNF content rapidly decreased to $10 \%$ of the original within $6 \mathrm{~h}$ (Fig. $8 \mathrm{~B}$ ), demonstrating that administered BDNF was physiologically available only for several hours even when high amounts had been injected.

\section{S-phase-dependent responsiveness of progenitors to BDNF}

Transplantation experiments suggest that the laminar fate of mid- and deep-layer neurons is decided by unknown environmental cues to which their parent progenitors respond at approximately S-phase (McConnell and Kaznowski, 1991; Desai and McConnell, 2000). Therefore, these findings prompted us to investigate whether the action of BDNF depended on the cell cycle.

In the ICZ of E13 and E14 mouse cortices, the lengths of the phases of the cell cycle of progenitors are reported to be more than 6.2 and 9.3-9.8 $\mathrm{h}\left(\mathrm{T}_{\mathrm{G} 1}\right), 3.9$ and $3.8-4.4 \mathrm{~h}\left(\mathrm{~T}_{\mathrm{S}}\right)$, and 2 and $2 \mathrm{~h}\left(\mathrm{~T}_{\mathrm{G} 2+\mathrm{M}}\right)$, respectively (Miyama et al., 1997). Because of the difference in the start time of experiments [5:00 P.M. in this study vs 9:00 A.M. in the study by Miyama et al. (1997)], the duration time of the cell-cycle length in E13.5 embryos, as estimated by cumulative BrdU-labeling and BrdU/IdU doublelabeling analyses (Table 1) (because $\mathrm{T}_{\mathrm{G} 2+\mathrm{M}}$ is known to be consistently $2 \mathrm{~h}, \mathrm{~T}_{\mathrm{G} 1}$ $=10.4 \mathrm{~h}$ ), was close to that of E14 embryos in the former study. Therefore, when BDNF was injected 1 and $6 \mathrm{~h}$ after BrdU on E13.5, the utmost labeled cells were exposed to BDNF in late $G_{1}$-phase to early $\mathrm{G}_{1}$-phase in the next cell cycle and in S- to late $G_{1}$-phase in the next cell cycle at the respective times (Fig. $8 C, D$ ), if we calculated each duration time of the action of BDNF and BrdU labeling to be $3 \mathrm{~h}$ (Fig. $8 \mathrm{~B}$ ) and $5 \mathrm{~h}$ (Takahashi et al., 1995), respectively. By exactly the same logic, when BDNF was injected 6 and 3 h before BrdU on E13.5, the utmost cells that would have been labeled in S-phase cells had been exposed to BDNF in $\mathrm{G}_{2} / \mathrm{M}$-phase in the pre-round cell cycle to $S$-phase and $G_{1}$ - to $G_{2}+M$-phase in the respective times. Because the growth and the leaving fractions of the progenitors were not altered by the administration of BDNF (Tables 2, 3), the progenitors should have normally incorporated BrdU in either case.

BDNF could alter the laminar fate of neurons only if their parent progenitors were continuously exposed to it to some extent at approximately $S$-phase, for example, $3 \mathrm{~h}$ before or $1 \mathrm{~h}$ after BrdU injection (Fig. 8E,F). In the developing cerebral cortex, neurogenesis is initiated rostrolaterally and progresses along the caudomedial axis of the epithelium in a manner that reflects a transverse neurogenic gradient (Bayer and Altman, 1991). BDNF administered $3 \mathrm{~h}$ before BrdU injection altered the migratory position of the BrdU-labeled neurons from the expected layers IV 
and V to layers V and VI in the dorsomedial cortical zone but did not influence the position of those neurons in the lateral cortical zone, in which layer II/III neurons were generated at the same time point (data not shown).

\section{Endogenous BDNF participates in the determination of laminar fate}

Consistent with previous studies on the embryonic rat cortex (Behar et al., 1997; Fukumitsu et al., 1998), low but significant levels of transcripts encoding BDNF and the full-length TrkB were detected between E13.5 and E18.5, when mouse cerebral cortices were examined by using semiquantitative RT-PCR. Tissue from the E13.5 cortex contained nearly 15 and 30\% of the levels of BDNF and TrkB mRNAs, respectively, found in the adult cortex (supplemental Fig. 3, available at www. jneurosci.org as supplemental material). Therefore, we analyzed the effect of endogenous BDNF on the laminar fate of cortical neurons. Anti-BDNF chick IgY antibody, which functionally and specifically neutralizes BDNF activity, was injected into the ventricular space of E13.5 mouse embryos, and then the ventricular mitotic progenitors were labeled by intraperitoneal BrdU injection. Immunostaining analysis demonstrated that the anti-BDNF antibody penetrated into areas from the $\mathrm{VZ}$ to the IZ, but not into the $\mathrm{CP}$, within $3 \mathrm{~h}$ after administration (Fig. 9E), implying that endogenous BDNF could be inactivated regionally. Neurons of layers II/III expressing Brn1 were slightly but significantly decreased in number (Table 1), but the total numbers of $\mathrm{BrdU}^{+}$cells in layers $\mathrm{I}-\mathrm{VI}$ and $\mathrm{BrdU}^{+}$cells expressing Brn1 were slightly and dramatically increased, respectively, in the antibody-treated cerebral cortex (Fig. 9A,B) (Table 1). The expression profiles of the genes specific to the respective layers (Fig. 9D) and the number of PIpositive cells comprising each sector were essentially similar in control IgY-treated and anti-BDNF antibody IgY-treated cortices (data not shown). Although the slight reduction in the number of Brn $1^{+}$cells could be attributable to cell death, this reduction was too small to explain the increase in the number of $\mathrm{BrdU}^{+}$cells in layer II/III (Fig. 9C) or that in the ratio of Brn $1^{+}$cells to the total $\mathrm{BrdU}^{+}$cells in the anti-BDNF antibody-treated cortex (Table 1). Therefore, the increase in the number of $\mathrm{BrdU}^{+}$cells in the layers II/III by the antibody is caused by alteration of the laminar fate of the neurons newly generated from the progenitors rather than by a simple loss of the neurons of II/III layers and a consequent superficial transposition of the $\mathrm{BrdU}^{+}$cells with properties of layer IV neurons. That is, the destination of migration and the neuronal phenotype generated from BrdU-labeled E13.5 progenitors were altered in an opposite way in both BDNF-treated and BDNF antibody-treated cerebral cortices (Fig. 9A,B). This finding was confirmed by the fact that the opposite sequential phenomena preceded the laminar fate alteration in the BDNF antibody-treated cortex, such as lagged completion of the S-phase
B $\quad \operatorname{Pax6}^{\mathrm{p}} \quad \operatorname{Pax}^{\mathrm{m}}$
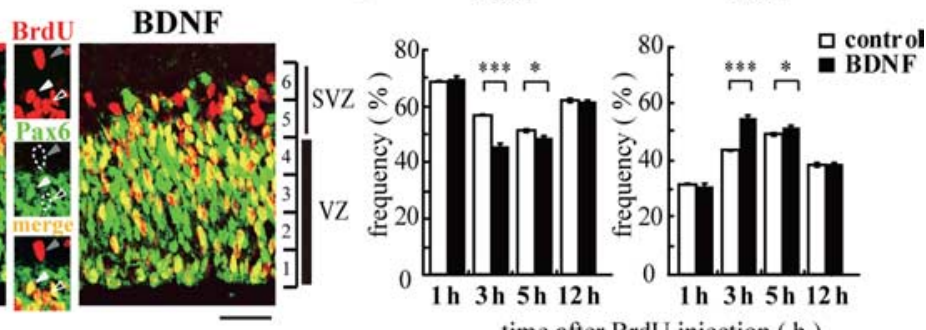

time after BrdU injection $(\mathrm{h}$ )

3h

$\square$ control - BDNF

$5 \mathbf{h}$
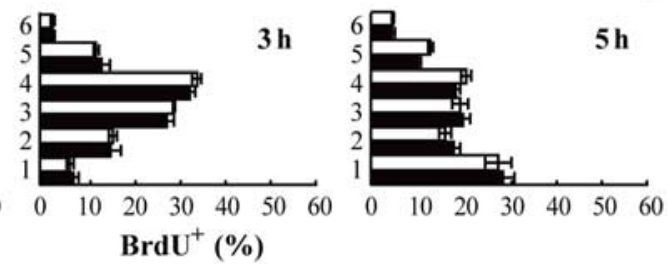

$5 \mathbf{h}$
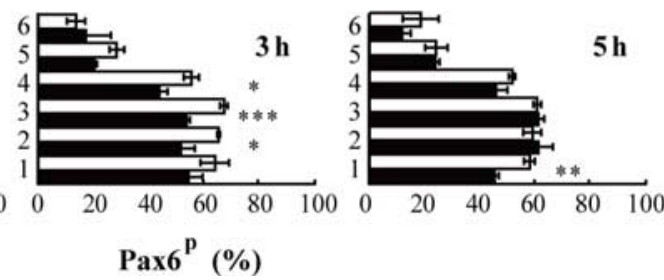

Figure 7. Progenitors expressing a lower level of Pax6 protein were increased in number after BDNF administration. BDNF (600 $\mathrm{ng}$ in $2 \mu$ l of PBS) was administered into the ventricular space of 13.5 mouse embryos $3 \mathrm{~h}$ after the injection of BrdU into pregnant mice. A, Double immunostaining for BrdU and Pax6 $3 \mathrm{~h}$ after the BrdU injection. Pax6 is expressed strongly (white arrowhead) (gray arrowhead), or not at all (open arrowhead) on the migrating BrdU cells. Scale bar, $50 \mu \mathrm{m}$. B, Quantitative mean \pm SE. ${ }^{*} p<0.05 ;{ }^{* * *} p<0.005$ (Student's $t$ test; $n=3$ ). C, Quantitative analysis of the distribution of BrdU ${ }^{+}$nuclei (top graphs) and the $\mathrm{Pax} 6^{\mathrm{P}} / \mathrm{BrdU}^{+}{ }^{+}$in the SVZ and VZ (bottom). The cerebral cortex was evenly divided into six parts, numbered from (bottom) in each sector from 1 to 6 (corresponding to SVZ/VZ) were counted. The values are expressed as the mean \pm SE. ${ }^{*} p<$ $0.05 ;{ }^{* * *} p<0.005$ (Student's $t$ test; $n=3$ ).

(control, $3.6 \pm 0.1 \mathrm{~h}$; anti-BDNF antibody, $4.3 \pm 0.1 \mathrm{~h} ; p<0.01$, Student's $t$ test; $n=3$ ). These results provide strong evidence for the involvement of endogenous BDNF in the processes that determine cortical laminar fate.

\section{Discussion}

The present study has identified BDNF as a putative environmental factor that regulates neural progenitors at the middevelopmental stage and determines the laminar fate of their daughter neurons in the mouse cerebral cortex.

Neural progenitors in the BDNF-injected brain were released more rapidly from the apical VZ into the basal VZ than those in the control brain by accelerated completion of the S-phase (Fig. 5) and faster interkinetic nuclear migration (Fig. 6) (supplemental Fig. 2, available at www.jneurosci.org as supplemental material). In general, the length of the cell cycle of the progenitors is known to increase with the progression of corticogenesis (Caviness et al., 1995; Takahashi et al., 1996) and progenitors generated in earlier stages, to proliferate more rapidly than those generated in later stages. Therefore, it is possible that a shortened cell cycle endows postmitotic cells with the properties of neurons generated much earlier. Indeed, BDNF altered the position and gene-expression properties of neurons that would otherwise have 
A

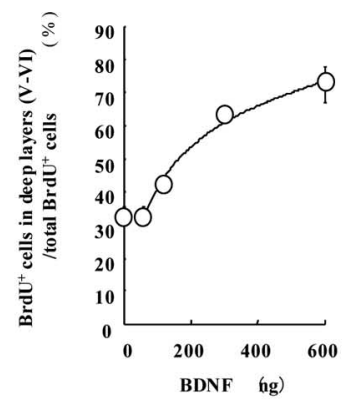

B

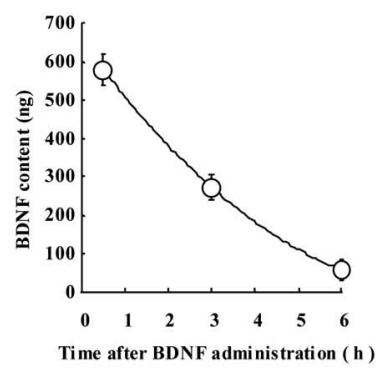

D
C

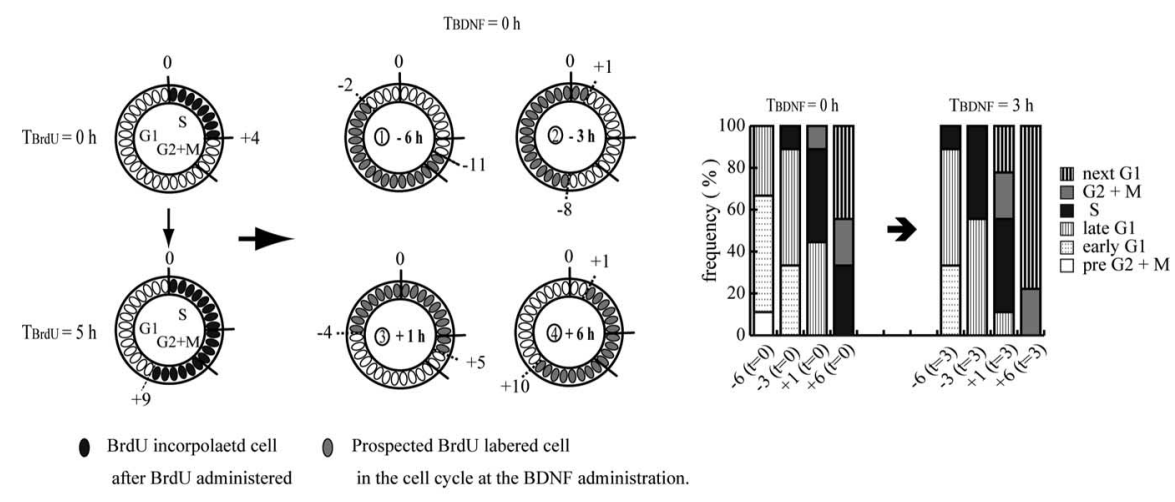

$\mathbf{E}$

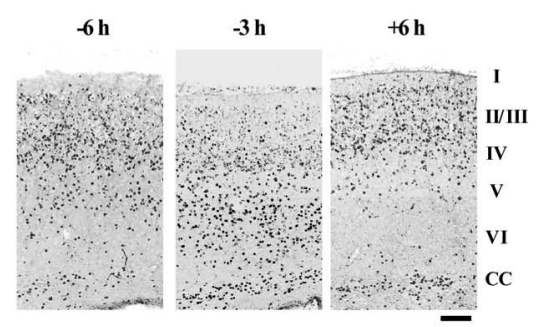

F

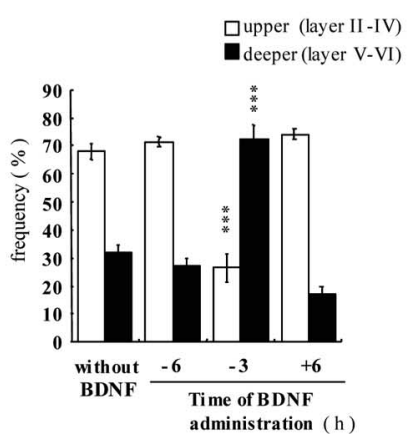

Figure 8. Dosage $(\boldsymbol{A})$, critical time point $(\boldsymbol{C}-\boldsymbol{F})$ for BDNF administration to alter laminar fate and time-dependent clearance from the brain of exogenous BDNF $(\boldsymbol{B})$. $\boldsymbol{A}$, Effect of BDNF dosage on the alteration of laminar fate. Values are expressed as means \pm SE of the numbers of $\mathrm{BrdU}^{+}$cells in deep layers ( $\mathrm{V}$ and $\left.\mathrm{VI}\right)$ expressed as percentages of the total numbers of BrdU ${ }^{+}$cells in layers II-VI. SEs are not shown when they were less than the width of the symbols $(n=4)$. $B$, Clearance of exogenously added BDNF from the brains of the embryos. BDNF content in whole-brain extracts was measured by a reliable two-site enzyme immunoassay for BDNF $(n=5)$ after injection of BDNF (600 ng in $2 \mu \mathrm{l}$ of PBS) into the ventricular space of E13.5 embryos. C, Protocol for determination of critical time point for BDNF administration to alter laminar fate. When BrdU were injected, nearly one-quarter of the proliferating cells were labeled $\left(\mathrm{T}_{\mathrm{BrdU}}=0 \mathrm{~h}\right.$ ) because $\mathrm{T}_{\mathrm{S}}=3-4 \mathrm{~h}$ and $\mathrm{T}_{\mathrm{C}}=15-16 \mathrm{~h}$. Because BrdU incorporation lasted for $5 \mathrm{~h}$, at the end of the labeling time $\left(\mathrm{T}_{\mathrm{BrdU}}=5 \mathrm{~h}\right)$, the BrdU-positive cells labeled at $\mathrm{T}_{\mathrm{BrdU}}=0 \mathrm{~h}$ in the late $\mathrm{S}$-phase should be in $\mathrm{G}_{1}$-phase of the next cycle. Because BDNF does not affect the final Q fraction, BrdU incorporation would not be affected by BDNF administration. Therefore, we have only to consider which phase the prospective BrdU incorporated cells were in at the time of BDNF administration $\left(\mathrm{T}_{\mathrm{BDNF}}=0 \mathrm{~h}\right)$ and half-life of BDNF $\left(T_{B D N F}=3 h\right)$. $D$, The ratio of BrdU cells in each phase of cell cycle at the time of BDNF administration $\left(T_{B D N F}=0 \mathrm{~h}\right)$ and half-life of BDNF $\left(\mathrm{T}_{\mathrm{BDNF}}=3 \mathrm{~h}\right) \cdot \boldsymbol{E}, \mathrm{BDNF}(600 \mathrm{ng}$ in $2 \mu$ l of PBS) was administered into the ventricular space of E13.5 mouse embryos 3 or $6 \mathrm{~h}$ before $(-3$ or -6$)$ or $6 \mathrm{~h}$ after $(+6)$ intraperitoneal injection of BrdU into pregnant mice carrying the experimental embryos. BrdU immunoreactivity in the cerebral cortex (CC) of P6 mice was visualized. Scale bar, $200 \mu \mathrm{m}$. F, BrdU ${ }^{+}$cell numbers in each sector as a percentage of the total number of BrdU ${ }^{+}$cells. Significant differences from the corresponding control (no treatment with BDNF) were determined by ANOVA with Tukey's post hoc test. ${ }^{* *} p<0.005(n=3)$.

been destined for layer IV to resemble those of the deeper layers, $\mathrm{V}$ and VI, of the cerebral cortex, and anti-BDNF antibody induced the properties of cells in the upper layers II/III (Figs. 1, 3, $9 A-C)$, a result that supports the involvement of endogenous
BDNF in the decision-making processes of neuronal laminar fate during corticogenesis. BDNF/TrkB signals affect the migratory destination of cortical neurons (Ohmiya et al., 2002; Medina et al., 2004) but have not yet been proven to regulate neuronal properties or phenotypes.

A growing number of reports suggest that cell-cycle regulators and neurogenic transcription factors act as intrinsic cues that influence neuron and glial cell fate commitment and the specification of neuronal phenotypes in the mammalian CNS (Dyer and Cepko, 2001; Morrison, 2001; Ross et al., 2003). In the cerebral cortex, increased generation of upper-layer neurons after a temporary reduction in midstage neurogenesis occurs in cyclindependent kinase inhibitor p $27^{\text {kip } 1}$ knockout mice (Goto et al., 2004), and the generation of glutamatergic deep-layer neurons is supported, whereas that of GABAergic neurons is suppressed, by Ngn1 (neurogenin homolog 1) and Ngn2 basic helix-loop-helix (bHLH) transcription factors (Schuurmans et al., 2004). Therefore, the timing of cell-cycle exit and the expression of transcription factors are important processes in the generation of deeper-layer neuron progeny. Neurotrophins, including BDNF, are known to increase the transcription of these intrinsic factors, including p $27^{\text {kip } 1}$ (Lukaszewicz et al., 2002), the bHLH transcription factors Mash1 and Math1 (Ito et al., 2003) and Ngn1 or Ngn2 (H. Fukumitsu, M. Sakai, and S. Furukawa, unpublished observation) in cultured cortical progenitors. Pax6 is a multifunctional transcription factor that promotes neuronal differentiation (Gotz et al., 1998) and proliferation of the ventricular progenitor cells (Warren and Price, 1997) in the developing cerebral cortex. It is also essential for production of upper-layer glutamatergic neurons (Schuurmans et al., 2004). If Pax6 signaling in late S-phase and/or transition phase from $S$ - to $G_{2}$-phase is necessary to adopt an upper-layer fate BDNF is likely to reduce the signals and cause the daughter neurons to revert to an earlier fate, because BDNF downregulated Pax6 expression (Fig. 7). In any case, we consider the hastened S-phase completion by faster interkinetic nuclear migration in the $\mathrm{VZ}$ as an explanation of BDNF actions to determine the laminar fate of daughter neurons generated from target progenitors.

So far, transplantation experiments have suggested that a combination of intrinsic and environmental cues controls the competence of cortical progenitors to produce neurons of different layers. The commitment of early-stage progenitors to the generation of deep-layer neuron progeny is 
influenced by environmental cues of the host cortex produced when the progenitors are cycling in late $S$ to $G_{2}$ transition, but the laminar fate of the daughter neurons is not affected by these environmental cues when the progenitors are outside of this critical period (McConnell and Kaznowski, 1991). Moreover, the competence of progenitors to produce multiple layers decreases with advancing developmental stage. When midstage (for layer IV) and later-stage (for layer II/III) progenitors are transplanted into a younger cortex for generation of layer VI neurons, their daughter neurons migrate to layers V (Desai and McConnell, 2000) and II/III (Frantz and McConnell, 1996), respectively. These observations are consistent with our previous finding that the progenitors of layer IV neurons, but not those of layer II/III neurons, have their destiny altered to become layer V and VI neurons by BDNF treatment (Ohmiya et al., 2002), a finding that demonstrates the stage-dependent action of BDNF. In the present study, BDNF altered the destiny of progenitors of layer IV neurons so that they generated layer V and VI neurons (Figs. 1, 3 ), and the action of BDNF was specific for the S-phase of the cell cycle (Fig. $8 C-F$ ).

The birthdate of neurons is widely accepted to be intimately linked to their laminar destination. During cortical neurogenesis, a day-by-day increase in the cell-cycle length of the parent progenitors depends on the increase in the length of the $G_{1}$-phase. Namely, phases other than $\mathrm{G}_{1}$ are constant during corticogenesis (Caviness et al., 1995; Takahashi et al., 1996). However, our present results demonstrated that BDNF shortened the $\mathrm{S}$-phase length without affecting $\mathrm{G}_{1}$-phase length and altered the progenitor fate to generate much deeper layer neurons, suggesting that unidentified events other than the length of cell cycle might be responsible for the BDNF-induced laminar fate decision. Indeed, when the earlier-born progenitors cultured as explants or at a low cell density were in S-phase, they generated deeper (V and VI) or upper (II/III) layer neurons after transplantation into older host cortex, respectively, although progenitor cells in both cultures had an S-phase twice as long as that of progenitor cells in vivo (Bohner et al., 1997). These experimental manipulations have thus decoupled S-phase, the sensitive period, and laminar fate decisions, suggesting that S-phase length is not involved directly in laminar fate determination. A recent report showed that disruption of the tlx (vertebrate homologue Drosophila tailless gene) gene shortened the cell-cycle length
A
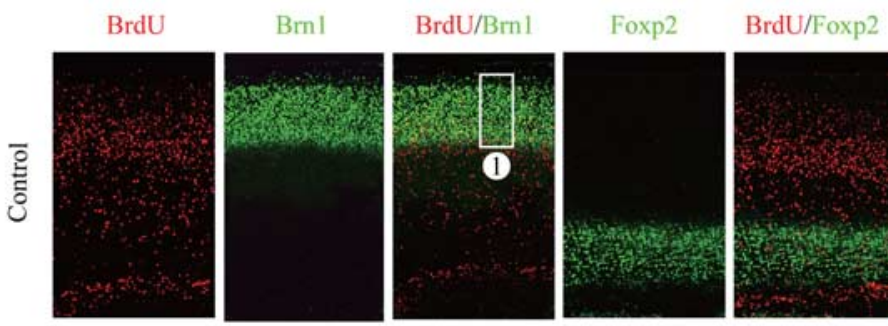

PI
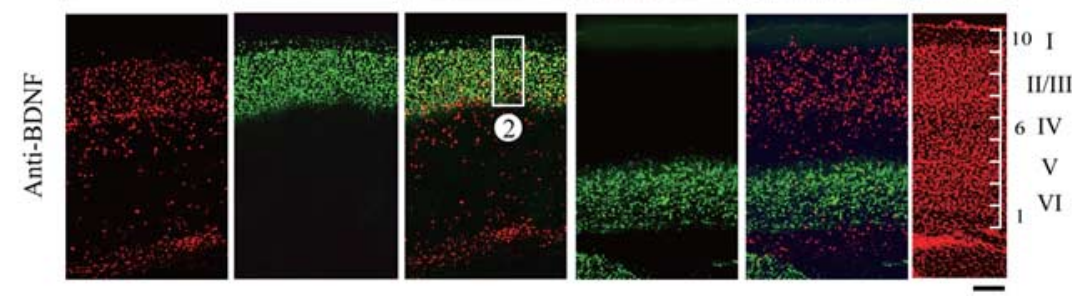

B

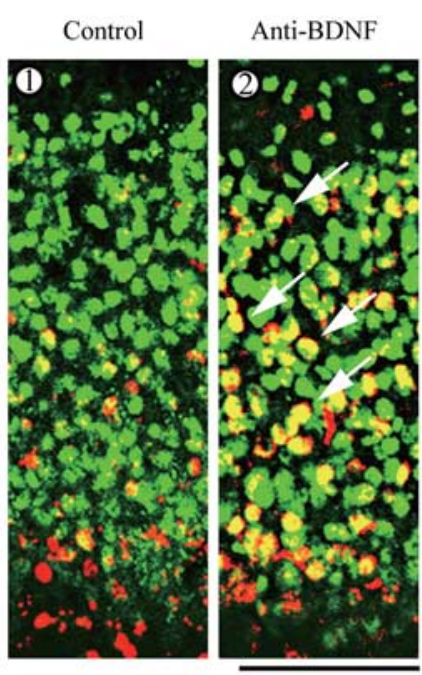

C
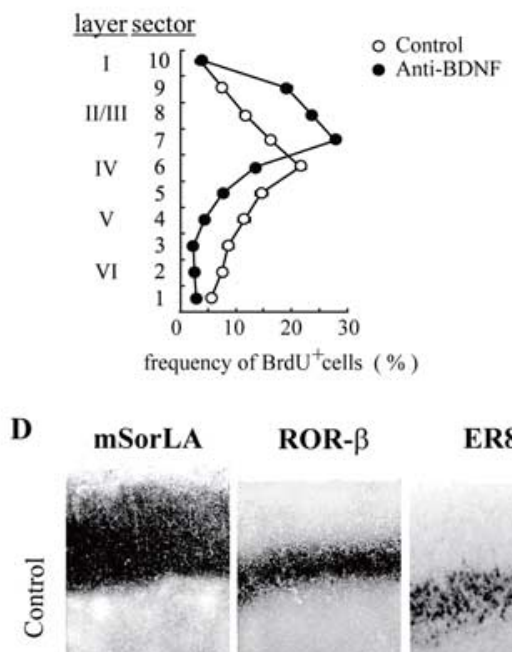

ROR- $\beta$

ER81

E
Anti-BDNF

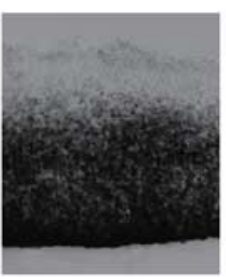

PBS

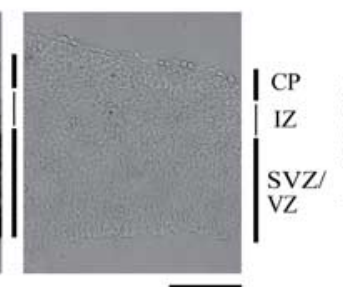

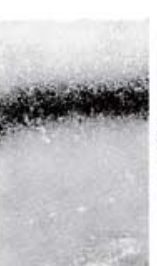

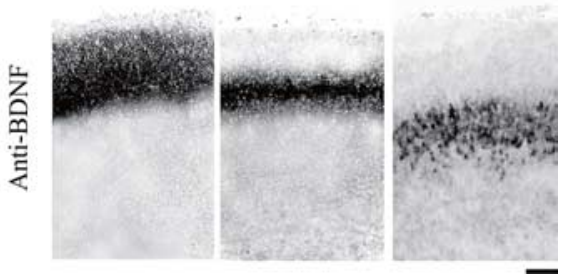

Figure 9. Involvement of endogenous BDNF in regulation of laminar fate determination in cortical progenitors. $A$, Antibody able to neutralize BDNF activity was administered into the ventricular space of E13.5 mice, and progenitors were labeled with BrdU $3 \mathrm{~h}$ after administration of the antibody. BrdU was visualized in brain sections including the cortices of the experimental mice at $\mathrm{P} 6$, and the sections were further stained with antibodies for lamina-specific markers (green; Brn1 for layer II/III or Foxp2 for layer $\mathrm{VI}$ ). Scale bar, $200 \mu \mathrm{m} . \boldsymbol{B}$, Enlarged views of layers II/III. The boxed areas numbered 1 and 2 in $A$ are enlarged. These photos reveal that substantial numbers of Brn1-positive cells were BrdU ${ }^{+}$in anti-BDNF antibody-treated cortices compared with their number in normal chicken IgY-treated cortices as control. BrdU ${ }^{+} / \mathrm{Brn}^{+}{ }^{+}$cells had increased in number in the anti-BDNF antibody-treated cerebral cortex (short arrows in 2) compared with their number in the normal chicken IgY-treated one (1). Scale bar, 200 $\mu \mathrm{m}$. C, The percentage of $\mathrm{BrdU}^{+}$cells in each sector. The values are expressed as the mean $\pm \mathrm{SE}$, but the SE is not shown when it is less than the width of the symbols. In anti-BDNF antibody-treated animals, the proportion of cells migrating to layers II/III among the whole BrdU ${ }^{+}$cells was significantly higher than that in the normal chicken IgY-treated animals (II/III, $67.5 \pm 1.4$ vs $32.8 \pm 1.4 \%$; IV-VI, $31.6 \pm 1.5$ vs $64.3 \pm 1.6 \% ; p<0.0001$ and $p<0.001$, respectively, Student's $t$ test; $n=4)$. D, Expression of layer-specific mRNAs (mSorLA, ROR- $\beta$, and ER81) in the cerebral cortex of a P6 mouse analyzed by in situ hybridization after administration of anti-BDNF antibody (bottom) or normal IgY (top) at E13.5. Blocking the BDNF function altered the destination of BrdU-labeled neurons so that they occupied much upper layers, but it did not alter the distribution of layer-specific mRNA. $\boldsymbol{E}$, Visualization of antibody after diffusion into the VZ $3 \mathrm{~h}$ after administration. Tissue sections were reacted with chick IgY antibody against BDNF and then with alkaline phosphataselabeled rabbit antibody against chick IgY. Scale bar, $100 \mu \mathrm{m}$. 
of the progenitor cells, resulting in increase of the BrdU-labeling index and in acceleration of the interkinetic nuclear migration during early to mid but not in late cortical neurogenesis (Roy et al., 2004). Because this observation is similar to our result showing the effect of BDNF on the progenitors, it may be possible that BDNF would influence the function of $t l x$-like transcription factors to affect precocious neurogenesis (Table 3 ) and would induce the laminar fate alteration of the newly generated neurons under reduced level of Pax6 expression. Indeed, complete loss of upper layer neurons has been shown at least in the anterior cerebral cortex of mice disrupted with both tlx and Pax6 genes (Schuurmans et al., 2004).

In this study, we observed no significant changes in number of the cells composed in each layer after BDNF or anti-BDNF antibody treatment. Furthermore, laminar structures were not stirred (Figs. 2A, 9D). Therefore, we estimated the number of the cells whose laminar fate was changed by BDNF. Percentage of $\mathrm{BrdU}^{+}$cells to the total cells of the cerebral cortex (PI-stained cells) was nearly $10 \%$ (data not shown), and $40 \%$ of the $\mathrm{BrdU}^{+}$ cells were susceptible for BDNF to shift to the deeper layers (Fig. $8 C, D)$. Therefore, only $4 \%$ of the total cortical cells had their laminar fate changed, suggesting that cell number is too small to detect the alteration of laminar structures. Furthermore, BDNF administration reduced $\mathrm{Brn}^{+} / \mathrm{BrdU}^{+}$cells from 28.0 to $13.3 \%$ and increased Foxp $2^{+} / \mathrm{BrdU}^{+}$cells from 7.9 to $17.0 \%$. The $14.7 \%$ reduction of $\mathrm{Brn} 1^{+} / \mathrm{BrdU}^{+}$cells imply that $1.5 \%$ of the total cortical cells were lost from layers II/III, and the $9.1 \%$ increment of Foxp $2^{+} / \mathrm{BrdU}^{+}$cells means that $0.9 \%$ cells of the total cells were increased in layers V-VI. Therefore, only a small portion of the cortical cells altered their laminar fate after treatment with BDNF or its antibody, which is likely to be one of the reasons why lamination profile was not changed.

Only a slight reduction in the thickness, but no gross abnormality, of the cortical laminas has been found in the cerebral cortex of $b d n f$ gene-disrupted mice [BDNF null mutants (Jones et al., 1994); early-onset forebrain-specific BDNF mutants (Gorski et al., 2003; Baquet et al., 2004)]. Therefore, the effects of BDNF or its antibody on laminar progenitors unveiled by the present study were unexpected. Our animal models treated with the antiBDNF antibody are different from $b d n f$ gene-disrupted animals in the following two respects: (1) onset and duration $(\sim 6 \mathrm{~h})$ of depletion of the BDNF downstream signaling from the cortex, and (2) only cells located in the area from the VZ to the IZ, but not in the CP, were affected, as judged by the penetration pattern and the effect of antibody on the laminar fate (Fig. 9E, and data not shown). In the previous study, we have shown that both neurotrophin-3/TrkC and BDNF/TrkB signaling systems are functionally expressed not only in the proliferating progenitor cells but also in the migrating and differentiating neurons in the IZ and CP (Fukumitsu et al., 1998). Therefore, in the anti-BDNF antibody-treated cortex, the BDNF signaling was only lost in the progenitor cells from approximately S-phase before neurogenesis but not in the later processes. It is conceivable that compensatory responses are activated in $b d n f$ gene-disrupted animals to minimize the effects of a lack of BDNF.

In conclusion, we found that BDNF accelerated the completion of S-phase associated with faster interkinetic migration of cortical progenitors. As a result, cortical progenitors during the midstages of corticogenesis in the BDNF-treated cortex were altered to produce much deeper-layer neurons. BDNF can therefore be counted as one of the key extrinsic factors that regulate the laminar fate of cortical neurons.

\section{References}

Angenvine JB, Sidman RL (1961) Autoradiographic study of cell migration during histogenesis of cerebral cortex in the mouse. Nature 192:766-768.

Baquet ZC, Gorski JA, Jones KR (2004) Early striatal dendrite deficits followed by neuron loss with advanced age in the absence of anterograde cortical brain-derived neurotrophic factor. J Neurosci 24:4250-4258.

Barnabe-Heider F, Miller FD (2003) Endogenously produced neurotrophins regulate survival and differentiation of cortical progenitors via distinct signaling pathways. J Neurosci 23:5149-5160.

Bayer SA, Altman J (1991) Neocortical development. New York: Raven.

Becker-Andre M, Wiesenberg I, Schaeren-Wiemers N, Andre E, Missbach M, Saurat JH, Carlberg C (1994) Pineal gland hormone melatonin binds and activates an orphan of the nuclear receptor superfamily. J Biol Chem 269:28531-28534.

Behar TN, Dugich-Djordjevic MM, Li Y-X, Ma W, Somogyi R, Wen X, Brown E, Scott C, McKay RDG, Barker JL (1997) Neurotrophins stimulate chemotaxis of embryonic cortical neurons. Eur J Neurosci 9:2561-2570.

Bohner AP, Akers RM, McConnell SK (1997) Induction of deep layer cortical neurons in vitro. Development 124:915-923.

Brunstrom JE, Gray-Swain MR, Osborne PA, Pearlman AL (1997) Neuronal heterotopias in the developing cerebral cortex produced by neurotrophin-4. Neuron 18:505-517.

Caviness Jr VS, Takahashi T, Nowakowski RS (1995) Numbers, time and neocortical neuronogenesis: a general developmental and evolutionary model. Trends Neurosci 18:379-383.

Caviness Jr VS, Goto T, Tarui T, Takahashi T, Bhide PG, Nowakowski RS (2003) Cell output, cell cycle duration and neuronal specification: a model of integrated mechanisms of the neocortical proliferative process. Cereb Cortex 13:592-598.

Desai AR, McConnell SK (2000) Progressive restriction in fate potential by neural progenitors during cerebral cortical development. Development 127:2863-2872.

Dyer MA, Cepko CL (2001) Regulating proliferation during retinal development. Nat Rev Neurosci 2:333-342.

Ferland RJ, Cherry TJ, Preware PO, Morrisey EE, Walsh CA (2003) Characterization of Foxp 2 and Foxp 1 mRNA and protein in the developing and mature brain. J Comp Neurol 460:266-279.

Frantz GD, McConnell SK (1996) Restriction of late cerebral cortical progenitors to an upper-layer fate. Neuron 17:55-61.

Fujita S (1963) The matrix cell and cytogenesis in the developing central nervous system. J Comp Neurol 120:37-42.

Fukumitsu H, Furukawa Y, Tsusaka M, Kinukawa H, Nitta A, Nomoto H, Mima T, Furukawa S (1998) Simultaneous expression of brain-derived neurotrophic factor and neurotrophin-3 in Cajal-Retzius, subplate and ventricular progenitor cells during early development stages of the rat cerebral cortex. Neuroscience 84:115-127.

Gilbert CD, Kelly JP (1975) The projections of cells in different layers of the cat's visual cortex. J Comp Neurol 163:81-105.

Gilbert CD, Wiesell TN (1985) Intrinsic connectivity and receptive field properties in visual cortex. Vision Res 25:365-374.

Gorski JA, Zeiler SR, Tamowski S, Jones KR (2003) Brain-derived neurotrophic factor is required for maintenance of cortical dendrites. J Neurosci 23:6856-6865.

Goto T, Mitsuhashi T, Takahashi T (2004) Altered patterns of neuron production in the p27kip knockout mouse. Dev Neurosci 26:208-217.

Gotz M, Stoykova A, Gruss P (1998) Pax6 controls radial glia differentiation in the cerebral cortex Neuron 21:1031-1044.

Hatta T, Morishima K, Nabeshima K, Taga T, Otani H (2002) The role of gp130 in cerebral cortical development: in vivo functional analysis in a mouse exo utero system. J Neurosci 22:5516-5524.

Hermans-Borgmeyer I, Hampe W, Schinke B, Methner A, Nykjaer A, Susens U, Fenger U, Herbarth B, Schaller HC (1998) Unique expression pattern of a novel mosaic receptor in the developing cerebral cortex. Mech Dev 70:65-76.

Hevner RF, Shi L, Justice N, Hsueh Y, Sheng M, Smiga S, Bulfone A, Goffinet AM, Campagnoni AT, Rubenstein JL (2001) Tbr1 regulates differentiation of the preplate and layer 6. Neuron 29:353-366.

Hevner RF, Daza RA, Rubenstein JL, Stunnenberg H, Olavarria JF, Englund C (2003) Beyond laminar fate: toward a molecular classification of cortical projection/pyramidal neurons. Dev Neurosci 25:139-151.

Huang EJ, Reichardt LF (2001) Neurotrophins: roles in neuronal development and function. Annu Rev Neurosci 24:677-736. 
Ito H, Nakajima A, Nomoto H, Furukawa S (2003) Neurotrophins facilitate neuronal differentiation of cultured neural stem cells via induction of mRNA expression of basic helix-loop-helix transcription factors Mash1 and Math1. J Neurosci Res 71:648-658.

Jones KR, Farinas I, Backus C, Reichardt LF (1994) Targeted disruption of the BDNF gene perturbs brain and sensory neuron development but not motor neuron development. Cell 76:989-999.

Kanegae Y, Lee G, Sato Y, Tanaka M, Nakai M, Sakaki T, Sugano S, Saito I (1995) Efficient gene activation in mammalian cells by using recombinant adenovirus expressing site-specific Cre recombinase. Nucleic Acid Res 23:3816-3821.

Lu B (2003) BDNF and activity-dependent synaptic function. Learn Mem $10: 86-98$.

Lukaszewicz A, Savatier P, Cortay V, Kennedy H, Dehay C (2002) Contrasting effects of basic fibroblast growth factor and neurotrophin 3 on cell cycle kinetics of mouse cortical stem cells. J Neurosci 22:6610-6622.

Maisonpierre PC, Belluscio L, Friedman B, Alderson RF, Wiegand SJ, Furth ME, Lindsay RM, Yancopoulos GD (1990) NT-3, BDNF, and NGF in the developing rat nervous system: parallel as well as reciprocal patterns of expression. Neuron 5:501-509.

McConnell SK, Kaznowski CE (1991) Cell cycle dependence of laminar determination in developing neocortex. Science 254:282-285.

McEvilly RJ, de Diaz MO, Schonemann MD, Hooshmand F, Rosenfeld MG (2002) Transcriptional regulation of cortical neuron migration by POU domain factors. Science 295:1528-1532.

Medina DL, Sciarretta C, Calella AM, Von Bohlen Und Halbach O, Unsicker $\mathrm{K}$, Minichiello L (2004) TrkB regulates neocortex formation through the Shc/PLC $\gamma$-mediated control of neuronal migration. EMBO J 23:3803-3814.

Miyama S, Takahashi T, Nowakowski RS, Caviness Jr VS (1997) A gradient in the duration of the G1 phase in the murine neocortical proliferative epithelium. Cereb Cortex 7:678-689.

Morrison SJ (2001) Neuronal potential and lineage determination by neural stem cells. Curr Opin Cell Biol 13:666-672.

Nieto M, Monuki ES, Tang H, Imitola J, Haubst N, Khoury SJ, Cunningham J, Gotz M, Walsh CA (2004) Expression of Cux-1 and Cux-2 in the subventricular zone and upper layers II-IV of the cerebral cortex. J Comp Neurol 479:168-180.

Nitta A, Ohmiya M, Jin-nouchi T, Sometani A, Asami T, Kinukawa H, Fukumitsu H, Nomoto H, Furukawa S (1999) Endogenous neurotrophin-3 is retrogradely transported in the rat sciatic nerve. Neuroscience 88:679-685.

Nowakowski RS, Lewin SB, Miller MW (1989) Bromodeoxyuridine immunohistochemical determination of the lengths of the cell cycle and the
DNA-synthetic phase for an anatomically defined population. J Neurocytol 18:311-318.

Ohmiya M, Shudai T, Nitta A, Nomoto H, Furukawa Y, Furukawa S (2002) Brain-derived neurotrophic factor alters cell migration of particular progenitors in the developing mouse cerebral cortex. Neurosci Lett 317:21-24.

Paxinos G, Franklin K (2001) The mouse brain in stereotaxic coordinates, Ed 2. London: Academic.

Polleux F, Dehay C, Kennedy H (1998) Neurogenesis and commitment of corticospinal neurons in reeler. J Neurosci 18:9910-9923.

Rakic P (1974) Neuron in rhesus monkey visual cortex: systematic relation between time of origin and eventual disposition. Science 183:425-427.

Rice DS, Curran T (1999) Mutant mice with scrambled brains: understanding the signaling pathways that control cell positioning in the CNS. Genes Dev 13:2758-2773.

Ringstedt T, Linnarsson S, Wagner J, Lendahl U, Kokaia Z, Arenas E, Ernfors P, Ibanez CF (1998) BDNF regulates reelin expression and Cajal-Retzius cell development in the cerebral cortex. Neuron 21:305-315.

Ross SE, Greenberg ME, Stiles CD (2003) Basic helix-loop-helix factors in cortical development. Neuron 39:13-25.

Roy K, Kuznicki K, Wu Q, Sun Z, Bock D, Schutz G, Vranich N, Monaghan AP (2004) The Tlx gene regulates the timing of neurogenesis in the cortex. J Neurosci 24:8333-8345.

Schuurmans C, Armant O, Nieto M, Stenman JM, Britz O, Klenin N, Brown C, Langevin LM, Seibt J, Tang H, Cunningham JM, Dyck R, Walsh C, Campbell K, Polleux F, Guillemot F (2004) Sequential phases of cortical specification involve neurogenin-dependent and -independent pathways. EMBO J 23:2892-2902.

Soriano E, del Rio JA (2005) The cells of Cajal-Retzius: still a mystery one century after. Neuron 46:389-394.

Takahashi T, Nowakowski RS, Caviness Jr VS (1995) The cell cycle of the pseudostratified ventricular epithelium of the embryonic murine cerebral wall. J Neurosci 15:6046-6057.

Takahashi T, Nowakowski RS, Caviness Jr VS (1996) The leaving or Q fraction of the murine cerebral proliferative epithelium: a general model of neocortical neuronogenesis. J Neurosci 16:6183-6196.

Tarabykin V, Stoykova A, Usman N, Gruss P (2001) Cortical upper layer neurons derived from subventricular zone as indicated by Svetl gene expression. Development 128:1983-1993.

Tole S, Chirstian C, Grove EA (1997) Early specification and autonomous development of cortical fields in the mouse hippocampus. Development 124:4959-4970.

Warren N, Price DJ (1997) Roles of Pax-6 in murine diencephalic development. Development 124:1573-1582. 